\title{
Dynamics of dissolved reactive phosphorus loss from phosphorus source and sink soils in tile-drained systems
}

\author{
P. Welikhe, S.M. Brouder, J.J. Volenec, M. Gitau, and R.F. Turco
}

\begin{abstract}
Understanding the processes controlling dissolved reactive phosphorus (DRP) loss in tile-drained systems is essential to better define critical source areas and inform nutrient and conservation practice recommendations. Concentration-discharge (C-Q) relationships have been used to infer solute sources, reactivity, proximity, and transport mechanisms governing solute fluxes. In this study, we compare DRP loads and flow-weighted mean DRP (FDRP) concentrations from $\mathrm{P}$ source and sink soils at an annual and event scale, and use power law analysis coupled with index-based approaches in order to identify the predominant DRP C-Q behavior in these soils at a daily and event scale. Results indicate that, in general, P source soils consistently lost higher DRP loads and exhibited greater FDRP concentrations when compared to $\mathrm{P}$ sink soils when examined at both annual and event scales. At the daily scale, C-Q patterns were linked to the soil $\mathrm{P}$ status whereby a chemostatic $(b=1)$ and dilution $(b<1)$ behavior was observed for $\mathrm{P}$ source and $\mathrm{P}$ sink soils, respectively. At the event scale, C-Q patterns were linked to soil $\mathrm{P}$ status with a potential contributing influence of flow path connectivity and mixing of event water with matrix and shallow groundwater. Events in $\mathrm{P}$ source soils had variable hysteretic behavior with $21 \%, 7 \%, 6 \%, 9 \%$, and $15 \%$ exhibiting anticlockwise with dilution, anticlockwise with flushing, clockwise with dilution, clockwise with flushing, and no hysteresis behavior, respectively. These variable C-Q responses suggest that, in addition to discharge and soil $\mathrm{P}$ status, rapid exchanges between $\mathrm{P}$ pools, the magnitude of discharge events (Q), and the relative number of days to discharge peak (RL) also regulated solute delivery. On the other hand, the predominant nonhysteretic C-Q behavior of events in P sink soils (67\%) suggests that DRP loss from these soils can be discounted. These findings highlight the need for nutrient and conservation practices addressing $\mathrm{P}$ draw down, $\mathrm{P}$ sequestration, and $\mathrm{P}$ supply according to crop need, which will likely be required to convert $\mathrm{P}$ sources to sinks and to avoid the conversion of $\mathrm{P}$ sinks to $\mathrm{P}$ sources.
\end{abstract}

Key words: concentration-discharge-hysteresis-phosphorus sink soils-phosphorus source soils-water quality

\begin{abstract}
Subsurface dissolved reactive phosphorus (DRP) loss and its link with eutrophication of surface water bodies have been extensively researched in recent years, as a growing number of studies have established leaching as a significant pathway for DRP loss to surface water, especially in tile-drained systems with long-term, repeated phosphorus $(P)$ applications (Gentry et al. 2007; Kinley et al. 2007; Sims et al. 1998). In poorly
\end{abstract}

drained soils, artificial drainage enhancements have significantly altered hydrology compared to naturally drained systems Installation of subsurface tile drains lowers water tables, reduces surface runoff, increases subsurface drainage, and consequently greatly impacts the fate and transport of nutrients from agricultural fields (Radcliffe et al. 2015 King et al. 2015). In many watersheds in the Midwest United States and Canada, tile discharge constitutes approximately $50 \%$ of the

Received January 20, 2021; Revised May 13, 2021; Accepted June 2, 2021; Published online October 28, 2021. streamflow. For example, King et al. (2014) found that tile discharge contributed $47 \%$ of annual watershed discharge in Ohio, and Macrae et al. (2007) reported that approximately $42 \%$ of annual watershed discharge in Ontario, Canada, originated from tile discharge. In these watersheds, the elevated levels of DRP in surface water links closely to the magnitude of tile discharge (King et al. 2014; Macrae et al. 2007). Indeed, studies have found that in some settings, tile drains exported equal amounts or more DRP loads as surface runoff. For example, Ruark et al. (2012) reported that in Wisconsin tiles supplied $16 \%$ to $58 \%$ of dissolved P loads. Similar elevated DRP loads from tile drains have been reported in other sites across North America and Europe (Gentry et al. 2007; Macrae et al. 2007; Gelbrecht et al. 2005).

High DRP concentrations are often measured in tile discharge (Welikhe et al. 2020a) despite the existence of high $\mathrm{P}$ sorption capacity of subsoils (Djodjic et al. 2006). Phosphorus rich surface soils have been identified as the primary source of $\mathrm{P}$ to tile drains. For instance, Welikhe et al. (2020a) showed that after a soil's $\mathrm{P}$ saturation ratio (PSR) exceeds a PSR threshold of 0.24 (i.e., attains solid phase $\mathrm{P}$ saturation), there was an 8-fold greater risk of DRP loss to tile discharge. Also, previous work using cesium (Cs)-137 and P-33 isotopes reported that elevated DRP concentrations in tile discharge originated from P-rich surface soils (Uusitalo et al.2001; Djodjic et al. 1999). The coincidence between elevated DRP concentrations and peak event water (new water) contribution to tile discharge, especially in no-till fields, suggests that the primary pathway for DRP from surface soils to tile drains is via preferential (macropore) flow pathways (Williams et al.2016;Vidon and Cuadra 2011; Simard et al. 2000). Further, Williams et al. (2016) hypothesized that P source soils could

Pauline Welikhe is a research scientist with Phospholutions, State College, Pennsylvania. Sylvie M. Brouder is a professor in the Department of Agronomy, Purdue University, West Lafayette, Indiana. Jeffrey J. Volenec is a professor in the Department of Agronomy, Purdue University, West Lafayette, Indiana. Margaret Gitau is an associate professor in the Department of Agriculture and Biological Engineering, Purdue University, West Lafayette, Indiana. Ronald F. Turco is a professor and department head in the Department of Agronomy, Purdue University, West Lafayette, Indiana. 
function as labile sources of $\mathrm{P}$ much like surface-applied P, resulting in DRP loss to tile drains throughout the year. Nevertheless, despite these studies highlighting the role of a soil's $\mathrm{P}$ status (i.e., a P source or P sink soil) and macropore flow pathways on DRP export in tile-drained systems, the dynamics of DRP loss during discharge events as influenced by source and sink soils remains understudied. Therefore, understanding when and how DRP is being exported at the field scale from soils with different $\mathrm{P}$ status is critical for efficient decision-making.

As nutrient concentrations exhibit varying responses to changing discharge rates (Godsey et al. 2009), previous studies have successfully used concentration (C)-discharge (Q) relationships to unravel active solute source areas and transport pathways in watersheds (Rose et al. 2018; Duncan et al. 2017a, 2017b; Bowes et al. 2015; Bende-Michl et al. 2013). Pioneer work by Johnson et al. (1969) on stream water chemistry provides the framework for C-Q data analysis using power law fits (equation 1):

$L=a Q^{b}$,

where L is flux or load of solute or sediment, $\mathrm{Q}$ is discharge flow rate, and $b$ is the slope of $\log (\mathrm{L})-\log (\mathrm{Q})$ linear regression. The authors showed that the $\mathrm{C}-\mathrm{Q}$ relationships can be classified as chemodynamic or chemostatic, depending on whether there is a significant or negligible variation in concentration, respectively, relative to discharge variation (Godsey et al. 2009; Rose et al. 2018). Large solute reservoirs associated with dissolution of geologic materials, and/ or anthropogenic-sourced solutes including legacy stores of nitrate $\mathrm{NO}_{3}^{-}$and $\mathrm{P}$ linked to long-term, repeated land applications are hypothesized to generate chemostatic C-Q relationships (Godsey et al. 2009; Basu et al. 2010; Thompson et al. 2011; Diamond 2013). On the other hand, flushing C-Q behavior is observed when solute or particulate concentrations increase with discharge $(b>1)$, whereas a dilution C-Q behavior is observed when solute or particulate concentrations decrease with increasing discharge $(b<1)$ (Godsey et al. 2009; Bieroza et al. 2018).

Whether chemostatic or chemodynamic, C-Q analysis often exhibits large dispersions of observations around the fitted relationship. One factor that causes the large dispersion in $\mathrm{C}-\mathrm{Q}$ plots is the presence of hysteresis due to existing source and transport limitations (Minaudo et al. 2019). These hysteretic patterns have been identified through visual inspection of graphical plots or through the use of metrics and indices that characterize and quantify hysteretic responses (Butturini et al. 2008; Lawler et al. 2006; Lloyd et al. 2016a, 2016b; Duncan et al. 2017a, 2017b). By classifying these C-Q hysteretic patterns and their succession, analyses revealed additional information on processes controlling solute transport to streams. A study by Williams (1989) on hysteresis patterns of suspended sediment was one of the first to outline the most common shapes for hysteresis loops and provided possible explanations for their occurrence. The author classified the loops into five classes. The first class is described as a single-valued straight line, suggesting that sediment concentrations and discharge are synchronized. This shape could occur when sediment concentrations are plentiful. Class two is a clockwise loop where peak sediment concentrations occur on the rising hydrograph limb. This shape suggests exhaustible sediment supply. In contrast, class three is an anticlockwise loop where sediment peak concentrations lag discharge peak, and solute concentrations are higher on the falling versus the rising hydrograph limb. This shape suggests differing transit times of sediment and water. Class four is a mix of classes one and two, i.e., a straight-line plus a loop, which results from a change in C-Q relationship during a storm event possibly due to changes in sediment availability, storage, and transport. Class five is also a combination of class two and three resulting in loops with a figure-of-eight configuration. This shift in loop shape is also possibly caused by a shift in the relationship between discharge and sediment concentrations. Recent studies have further added possible explanations for the different loop shapes observed. For example, clockwise hysteresis could also suggest either rapid mobilization or proximal sources to the stream, whereas anticlockwise hysteresis could also suggest either transport-limited systems, distal solute sources, or an eventual mix of solute contributions from early, low concentration sources, and late, high concentration sources (Chanat et al. 2002; Bowes et al. 2005; Bieroza and Heathwaite 2015; Vaughan et al. 2017).

The overall goal of this study was to quantify DRP losses from $\mathrm{P}$ source and $\mathrm{P}$ sink soils to tile drain waters and assess patterns of loss as a function of discharge. Specific objectives include the following: (1) determination of DRP loads and flow-weighted dissolved reactive phosphorus (FWDRP) concentrations from $\mathrm{P}$ source and sink soils at an annual and event-based time scale, and (2) evaluate the predominant C-Q responses of DRP from $\mathrm{P}$ source and sink soils in tile discharge. Our hypotheses were (1) DRP in source soils would display chemostatic behavior as indicated by $b=0$ due to legacy $\mathrm{P}$ sources buffering variations in DRP concentrations over a large range of Q; (2) DRP in sink soils would display a dilution behavior as indicated by $b<1$ due to greater $\mathrm{P}$ mobilization from P-limited soils under high Q conditions. Additionaly, the influences of hydrologic connectivity and mixing of drainage waters (matrix and shallow groundwater) on DRP C-Q dynamics were explored.

\section{Materials and Methods}

Site Description and Nutrient Management. The study was conducted between October 1,2010, and September 30, 2013 (three water years, i.e., water year 2011, 2012, and 2013, each beginning on October 1 and ending on September 30), at the Water Quality Field Station (WQFS), Purdue University. The predominant soil series at the site is Drummer silty clay loam with a small area $(<2 \%)$ of Raub silty clay loam. Slopes range from $0 \%$ to $2 \%$. At the WQFS, 48 treatments are arranged in a randomized complete-block design, with 12 treatments per block. The treatments consist of 1 native prairie mixture and 11 treatments representing common or emerging cropping systems in the Midwest United States. Of the 12 treatments, 3 biomass-for-bioenergy systems were considered in this study: Miscanthus $\times$ giganteus $(\mathrm{M} \times \mathrm{g})$, continuous maize (Zea mays L.) with residue removal (CM-RR), and switchgrass (Panicum virgatum) variety Shawnee (Switch) (table 1). These treatments were last tilled in 2006 (Switch) or 2007 (M×g and CM-RR) and had various $\mathrm{P}$ applications over the years. These no-till plots were the only ones considered in this study because tillage has been shown to disrupt macropore flow (Jarvis 2007), which is the major flow pathway for DRP to tile drains, especially in fine-textured soils (Beauchemin et al. 1998). Since 1997, treatment CM-RR received approximately $94 \mathrm{~L} \mathrm{ha}^{-1}$ of liquid starter fertilizer (17-17-0 $[17 \%(\mathrm{w} / \mathrm{w})$ nitrogen $(\mathrm{N})$ and $17 \%(\mathrm{w} / \mathrm{w})$ phosphorus pentoxide $\left.\left(\mathrm{P}_{2} \mathrm{O}_{5}\right)\right]$ in 1997 and 
19-17-0 [19\% (w/w) $\mathrm{N}$ and $17 \%(\mathrm{w} / \mathrm{w})$ $\mathrm{P}_{2} \mathrm{O}_{5}$ ] every year after) supplying $16 \mathrm{~kg} \mathrm{P}_{2} \mathrm{O}_{5}$ $\mathrm{ha}^{-1}$ with all maize plantings. Also, in April of 2012, replicates in the treatment received $43 \mathrm{~kg} \mathrm{P}_{2} \mathrm{O}_{5} \mathrm{ha}^{-1}$ from a $0-45-0$ fertilizer application. Similar liquid starter fertilizer applications were done with all maize plantings prior to treatment conversion to $\mathrm{M} \times \mathrm{g}$ and Switch in 2008 and 2007, respectively (table 1). All $\mathrm{P}$ fertilizer applications were based on Purdue University recommended rates that are dependent on soil test $\mathrm{P}$ levels (Vitosh et al. 1995).

Soils Data. The values for soil P storage capacity (SPSC) used in this study were determined (equation 2) and reported by Welikhe et al. (2020a) as follows:

$S P S C=(d 0-P S R) \times P S C_{E s t}$,

where $d 0$ is a change-point PSR value of 0.21 , PSR is an indivual soil's $\mathrm{P}$ saturation ratio, and $\mathrm{PSC}_{\mathrm{Est}}$ is a pedotransfer function used to accurately estimate a soil's P sorption capacity. Detailed descriptions of the determination of $d 0$, PSR, PSC $\mathrm{Est}_{\text {, }}$ and chemical characterization of samples are available in Welikhe et al. (2020a). The SPSC values range from negative to positive, where negative and positive values are estimates of loosely (easily desorbed) and firmly held legacy P in soils, respectively (Nair et al. 2015; Nair and Harris 2014; Welikhe et al. 2020a).
Therefore, individual replicate SPSC values were used to identify a plot's P status. For the purpose of this study, plots considered were those that consistently had either negative SPSC values ( $\mathrm{P}$ saturated referred to as " $\mathrm{P}$ source soils" in this work) or postive SPSC values ( $\mathrm{P}$ unsaturated referred to as " $\mathrm{P}$ sink soils" in this work) throughout the monitoring period. Therefore, plots 46 and 18 were excluded from this analysis because their $\mathrm{P}$ statuses varied throughout the study period (table 2). Based on their SPSC values, plots 10,11 , and 12 were classified as P source soils (negative SPSC values), while plots 26, 30, 32,43 , and 44 were classified as P sink soils (positive SPSC values).

Flow and Dissolved Reactive Phosphorus Concentration Data Collection. In each treatment plot at the WQFS $(10.8 \times 48 \mathrm{~m})$, an in-ground drainage lysimeter $(24 \times 9 \mathrm{~m})$ is constructed as a bottomless clay box to create a hydrologically isolated area from which drain-flow is collected. Lysimeter walls are Bentonite slurry to a depth of $1.5 \mathrm{~m}$. Two parallel, plastic tiles (collection tile and companion tile), $0.1 \mathrm{~m}$ in diameter, are installed at a depth of $0.9 \mathrm{~m}$ in the longitudinal centers of the plots. The collection tile drains the areas within the lysimeter while the companion tile drains the areas outside the lysimeter. The companion tile drains into a nearby drainage ditch while the collection tile drains into instrument huts where stainless steel tipping buckets are positioned at the end of the drains to measure hourly discharge volumes. The tipping buckets are fitted with a magnetic sensor switch to count the number of tips that are recorded by data loggers and summarized by the hour. Hourly tip counts are converted to discharge volumes using calibration values unique to each tipping bucket. In our study, hourly discharge data were aggregated from noon to noon to create daily discharge data. A statistical protocol and decision rule developed by Trybula (2012) was used to identify and eliminate nonfunctioning tiles from further analysis. Based on these criteria, plot 22 and 23 of treatment $\mathrm{M} \times \mathrm{g}$ and CM-RR, respectively, were eliminated from the rest of the study (table 1).

To best correspond with daily discharge volumes, 24 hour flow-proportional discharge water quality samples were collected whenever drain discharge occurred. Once retrieved, the water samples were immediately transported to the laboratory, filtered $(0.45 \mu \mathrm{m}$ filter $)$, and filtrate DRP (orthophosphate) concentrations were analyzed colorimetrically by the Murphy and Riley (1962) procedure using a SEAL AQ2 auto-analyzer method EPA-118-A Rev.5 (equivalent to US Environmental Protection Agency [USEPA] method 365.1, Rev.2.0) (Seal Analytical 2004). Any samples not analyzed within 24 hours were frozen. The data on daily tile discharge and

\section{Table 1}

A brief description of current no-till treatments at the Water Quality Field Station (abbreviations and year of establishment [yr.est.]), any previous treatments (cropping systems and nitrogen [N] rates applied to maize) dating back to 1997, and phosphorus [P], N, and tillage management.

\begin{tabular}{|c|c|c|c|c|c|}
\hline $\begin{array}{l}\text { Current } \\
\text { treatment } \\
\text { (abbrev./yr.est.) }\end{array}$ & Plot* & 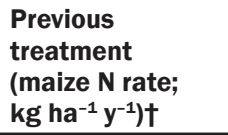 & $\begin{array}{l}\text { Current } \mathbf{N} \\
\text { management } \\
(\text { annual rate; } \\
\left.\text { kg ha }^{-1} \mathbf{y}^{-1}\right)\end{array}$ & $\begin{array}{l}P \text { management } \\
\text { (cumulative } P_{2} O_{5} \\
\text { applied } 1997 \text { to } \\
\left.2013 ; \mathrm{kg} \mathrm{ha}^{-1}\right) \ddagger\end{array}$ & $\begin{array}{l}\text { Tillage } \\
\text { practices }\end{array}$ \\
\hline $\begin{array}{l}\text { Miscanthus } \times \\
\text { giganteus } \\
(\mathrm{M} \times \mathrm{g} / 2008)\end{array}$ & $11, \mathbf{2 2}, 32,43$ & $\begin{array}{l}\text { Annual soybean- } \\
\text { maize rotation } \\
\text { (180-preplant) }\end{array}$ & $\begin{array}{l}\text { Spring broadcast } \\
\text { urea }(56)\end{array}$ & $\begin{array}{l}\text { Commercial fertilizer } \\
\text { based on STP (265) } \\
+ \text { starter (272) }\end{array}$ & $\begin{array}{l}\text { No-till } \\
\text { since } 2008\end{array}$ \\
\hline $\begin{array}{l}\text { Continuous maize } \\
\text { w/residue removal } \\
\text { (CM-RR/2008) }\end{array}$ & $12, \mathbf{2 3}, 30,46$ & $\begin{array}{l}\text { Continuous maize } \\
\text { w/ residue return } \\
\text { (202-preplant) }\end{array}$ & $\begin{array}{l}\text { Preplant UAN } \\
(180)+\text { starter }\end{array}$ & $\begin{array}{l}\text { Commercial fertilizer } \\
\text { based on STP (180) } \\
+ \text { starter (80) }\end{array}$ & $\begin{array}{l}\text { No-till } \\
\text { since } 2008\end{array}$ \\
\hline $\begin{array}{l}\text { Switchgrass var. } \\
\text { Shawnee } \\
\text { (Switch/2007) }\end{array}$ & $10,18,26,44$ & $\begin{array}{l}\text { Annual soybean- } \\
\text { maize rotation } \\
\text { (180-preplant) }\end{array}$ & $\begin{array}{l}\text { Spring broadcast } \\
\text { urea }(56)\end{array}$ & $\begin{array}{l}\text { Commercial fertilizer } \\
\text { based on STP (180) } \\
+ \text { starter (80) }\end{array}$ & $\begin{array}{l}\text { No-till } \\
\text { since } 2007\end{array}$ \\
\hline
\end{tabular}

*A bold plot number indicates a tile line that ceased to function, and the plot was therefore eliminated from the analysis of dissolved reactive phosphorus concentration-discharge relationships.

†Nitrogen rates are for the maize year in a rotation. All were preplant applications.

‡Estimate of cumulative phosphate applied from 1997 to 2013 are shown parenthetically. 
Table 2

Soil Phosphorus Storage Capacity (SPSC) and Soil Test Phosphorus (STP) for surface soils $(20 \mathrm{~cm})$ reported in Welikhe et al. (2020a). Negative and positive SPSC values are associated with P source and P sink soils, respectively. Years 2011, 2012, and 2013 are water years, e.g., 2011 water year begins on October 1, 2010, and ends on September 30, 2011. Refer to table 1 for descripion of treatments.

\begin{tabular}{|c|c|c|c|c|c|c|c|c|}
\hline \multirow[b]{2}{*}{$\begin{array}{l}\text { Current treatment } \\
\text { (abbrev./yr.est.)* }\end{array}$} & \multirow[b]{2}{*}{ Plot† } & \multicolumn{3}{|c|}{$\underline{\operatorname{SPSC}\left(\mathrm{L} \mathrm{kg}^{-1}\right)}$} & \multicolumn{3}{|c|}{$\underline{\text { STP }\left(\mathrm{mg} \mathrm{kg}^{-1}\right)}$} & \multirow[b]{2}{*}{ P status } \\
\hline & & 2011 & 2012 & 2013 & 2011 & 2012 & 2013 & \\
\hline Miscanthus $\times$ & 11 & -10.0 & -5.1 & -6.6 & 26 & 24 & 25 & P source \\
\hline giganteus & 32 & 35.0 & 41.0 & 41.8 & 9 & 8 & 8 & $P$ sink \\
\hline$(\mathrm{M} \times \mathrm{g} / 2008)$ & 43 & 20.6 & 23.8 & 28.4 & 13 & 12 & 11 & $P$ sink \\
\hline Continuous maize & 12 & -10.9 & -18.3 & -7.8 & 27 & 32 & 26 & P source \\
\hline Switchgrass var. & 10 & -2.6 & -1.3 & -2.6 & 22 & 22 & 23 & P source \\
\hline Shawnee & 18 & -4.30 & 10.41 & 19.31 & 23 & 17 & 14 & - \\
\hline \multirow[t]{2}{*}{ (Switch/2007) } & 26 & 12.9 & 28.0 & 32.8 & 15 & 11 & 10 & $P$ sink \\
\hline & 44 & 11.9 & 29.5 & 22.4 & 16 & 11 & 13 & $P$ sink \\
\hline
\end{tabular}

*abbrev./yr.est. = abbreviations and year of establishment.

†An italicized plot number indicates a plot whose P status varied between being a P source and a P sink soil during the study period, and the plot was therefore eliminated from the rest of the study.

DRP concentrations used for this study are archived in the Purdue University Research Repository (PURR) (Welikhe et al. 2020b). For a detailed description of flow processing, gap-filling of missing DRP values, handling of flow and DRP outliers, days with flooding, rainfall, and tile drain efficiencies, see Welikhe et al. (2020a). In this study, missing daily discharge data were not gap filled. A summary of the number of missing days is presented in table 3 .

Calculations and Statistical Analysis. All statistical analyses were performed in $\mathrm{R}$ 3.4.0. (R Core Team 2017). For a given tile, daily DRP loads were determined by multiplying the daily DRP concentration by the respective daily discharge volume. To reduce postive skewness in the daily discharge data and enable the use of log-log regression analyses, daily discharge volumes $<5 \mathrm{~L}\left(0.005 \mathrm{~m}^{3}\right)$ were removed from the data set (Welikhe et al. 2020b). Across all P source and sink soiks, $13 \%$ and $8 \%$ of the daily discharge observations were $<5 \mathrm{~L}\left(0.005 \mathrm{~m}^{3}\right)$. Daily DRP loads were summed for each tile on an annual (water year) and event basis. Flow-weighted DRP concentrations (FDRP) were calculated as the summed loads divided by the summed flow volumes on an annual and event basis. For our purposes, an event was defined as a composite sample with a total discharge $(\mathrm{Q}) \geq 100 \mathrm{~L}\left(0.1 \mathrm{~m}^{3}\right)$ per event to enable log-log regression analysis. Linear regression analysis (lm function) was used to characterize $\mathrm{C}-\mathrm{Q}$ relationships between DRP flux and discharge. The C-Q relation- ship was determined across the two time scales (daily and event) for each surface soil status ( $\mathrm{P}$ source and $\mathrm{P}$ sinks). For each time scale, data were log-transformed (logTransform function) before regression analysis to test $\mathrm{C}-\mathrm{Q}$ relationships for $\mathrm{P}$ source and $\mathrm{P}$ sink soils. DRP flux (l) was characterized as a function of discharge flow rate (Q) at both daily and event scales (equation 1). Ninetyfive percent confident intervals of $b$ (slope) were determined (confint function) to test whether $b$ was significantly different from 1 . $b$ values less than, equal to, and greater than 1 indicate solute dilution (decrease with discharge), no effect (chemostasis), and accretion (increase with discharge), respectively.

Determination of ConcentrationDischarge Hysteresis Loops. As previously mentioned, this study used low resolution (daily) data. Therefore, for our purpose, the following criteria were used to select discharge events to consider during hysteresis analysis: (1) having complete daily C and Q data for the entire discharge event, (2) discharge events with $\geq 3$ days of $\mathrm{C}$ and $\mathrm{Q}$ data, (3) discharge events that did not have more than one peak, and (4) discharge events with a peak tile discharge rate greater than $1 \mathrm{~mm}$ $\mathrm{d}^{-1} \mathrm{ha}^{-1}$. General characteristics of drainage events (event duration [ED]; days since the previous event $[\Delta \mathrm{t}]$; total event discharge [Q]; peak event discharge $\left[Q_{\text {max }}\right]$; average event discharge $\left[\mathrm{Q}_{\text {ave }}\right]$; relative length (days) of the rising limb $\left[\mathrm{D}_{\text {rel }} ; \mathrm{D}_{\text {rel }}=\right.$ (days of the rising limb of the hydrograph/days of the entire hydrograph) $\times 100$ ]) were determined.
For each discharge event, the analysis of DRP concentrations (C) versus discharge (Q) relationships was performed with the approach proposed by Butturini et al. (2006) and Butturini et al. (2008). Two simple, semiquantitative descriptors of solute behavior, $\Delta \mathrm{C}$ and $\Delta \mathrm{R}$, were used to describe the shapes, rotational patterns, and trends of DRP hysteretic loops during individual discharge events. The $\Delta \mathrm{C}$ quantifies the relative changes in solute concentrations at the onset of discharge and peak flow. The $\Delta \mathrm{C}(\%)$ is calculated as equation 3:

$\Delta \mathrm{C}(\%)=\frac{\mathrm{C}_{\mathrm{s}}-\mathrm{C}_{\mathrm{b}}}{\mathrm{C}_{\max }} \times 100$,

Table 3
The number of days with missing flow data
for tiles in the study plots. The percentage
of number of days with missing data per
water year is presented parenthetically.
\begin{tabular}{llll}
\multicolumn{4}{c}{ Days with missing flow data } \\
\cline { 2 - 4 } Tile & $\mathbf{2 0 1 1}$ & $\mathbf{2 0 1 2}$ & $\mathbf{2 0 1 3}$ \\
\hline 10 & $59(16)$ & $0(0)$ & $48(13)$ \\
11 & $59(16)$ & $0(0)$ & $48(13)$ \\
12 & $59(16)$ & $0(0)$ & $48(13)$ \\
26 & $60(16)$ & $0(0)$ & $128(35)$ \\
30 & $60(16)$ & $0(0)$ & $128(35)$ \\
32 & $0(0)$ & $0(0)$ & $41(11)$ \\
43 & $1(0.3)$ & $0(0)$ & $44(12)$ \\
44 & $1(0.3)$ & $0(0)$ & $44(12)$
\end{tabular}


where $\mathrm{C}_{\mathrm{b}}$ and $\mathrm{C}_{\mathrm{s}}$ are DRP concentrations at base flow and at peak discharge, respectively, and $\mathrm{C}_{\max }$ is the highest DRP concentration observed in the tile during a discharge event. To adapt this parameter to tile discharge with no base flow, we replaced $\mathrm{C}_{\mathrm{b}}$ with $\mathrm{C}_{\mathrm{i}}$, which is the DRP concentration at the beginning of the discharge event. Therefore, the modified $\Delta \mathrm{C}$ was calculated as equation 4 :

$\Delta \mathrm{C}(\%)=\frac{\mathrm{C}_{\mathrm{s}}-\mathrm{C}_{\mathrm{i}}}{\mathrm{C}_{\max }} \times 100$.

The $\Delta \mathrm{C}$ ranges between $-100 \%$ to $100 \%$, where $\Delta \mathrm{C}<-10 \%,-10 \% \leq \Delta \mathrm{C} \geq 10 \%(\Delta \mathrm{C}$ values between $-10 \%$ and $10 \%)$, and $\Delta \mathrm{C}>$ $10 \%$ represent solute dilution, neutral, and solute flushing, respectively (Butturini et al. 2008). A flushing solute trend is observed when solute concentrations increase with discharge $(b>1)$, whereas a dilution solute trend is observed when solute concentrations decrease with discharge $(b<1)$ (Godsey et al. 2009; Maher 2011; Vaughan et al. 2017; Hoagland et al. 2017). The minimum $\Delta \mathrm{C}$ $(-100 \%)$ is observed when $\mathrm{C}_{\mathrm{s}}=0$ and $\mathrm{C}_{\mathrm{i}}$ $=\mathrm{C}_{\max }$, while the maximum $\Delta \mathrm{C}(100 \%)$ is observed when $\mathrm{C}_{\mathrm{s}}=\mathrm{C}_{\text {max }}$ and $\mathrm{C}_{\mathrm{i}}=0$.

The $\Delta \mathrm{R}$ parameter (equation 5 ) integrates information about the rotational pattern $(\mathrm{R})$ and the area $\left(A_{h}\right)$ of the $C-Q$ loop (figure 1).

$\Delta R(\%)=\left(A_{h} \times R\right) \times 100$.

The $A_{h}$ was determined (polyarea function) after standardizing discharge and concentration values to a unity scale. Therefore, $A_{h}$ will be lower than one. An $A_{b}$ value closer to zero suggests that the relationship pattern is more linear, i.e., the concentrations in the rising limb are equal to the concentrations in the falling limb for the same discharge. When $A_{h}$ value is closer to one, the area of the hysteresis loop is large and the concentrations in the rising and falling limb are different. $\mathrm{R}$ represents the rotational pattern of the C-Q hysteresis loop. If the hysteresis loop is clockwise, then $\mathrm{R}=1$, if anticklockwise, $\mathrm{R}=-1$, and if there is no hysteresis or there is an unclear hysteresis (e.g., figure-of-eight-shaped loops), $\mathrm{R}=0$. The $\Delta \mathrm{R}$ also ranges between $-100 \%$ to $100 \%$, where $\Delta \mathrm{R}<-10 \%,-10 \% \leq \Delta \mathrm{R} \geq 10 \%(\Delta \mathrm{R}$ values between $-10 \%$ and $10 \%)$, and $\Delta \mathrm{R}>$ $10 \%$ represent anticlockwise loop, no loop, and clockwise loop, respectively (Butturini et al. 2008). Clockwise hysteresis (i.e., higher solute concentrations on the rising versus the falling hydrograph limb) suggests an exhaust-

\section{Figure 1}

Schematic illustration of the area $\left(A_{h}\right)$ and rotational pattern $(R)$ of a concentration-discharge (C-Q) loop for a drainage event with (a) anti-clockwise rotation, and (b) clockwise rotation. Colors represent loop direction over time.

(a)

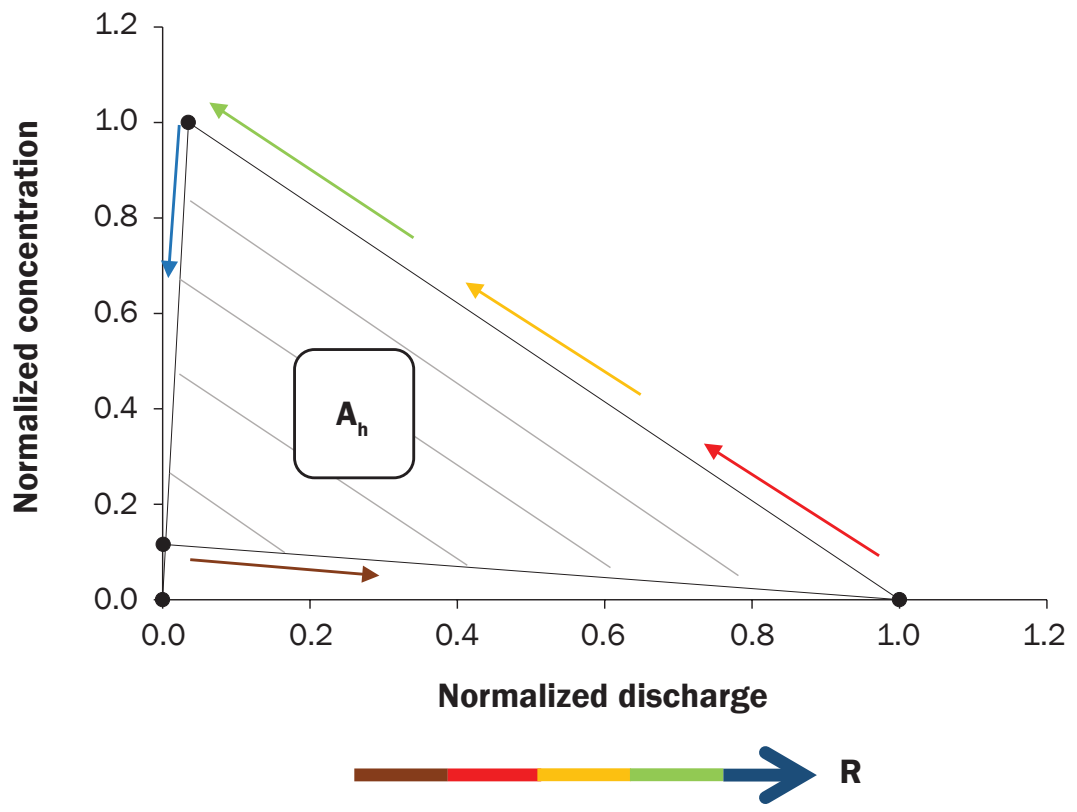

(b)

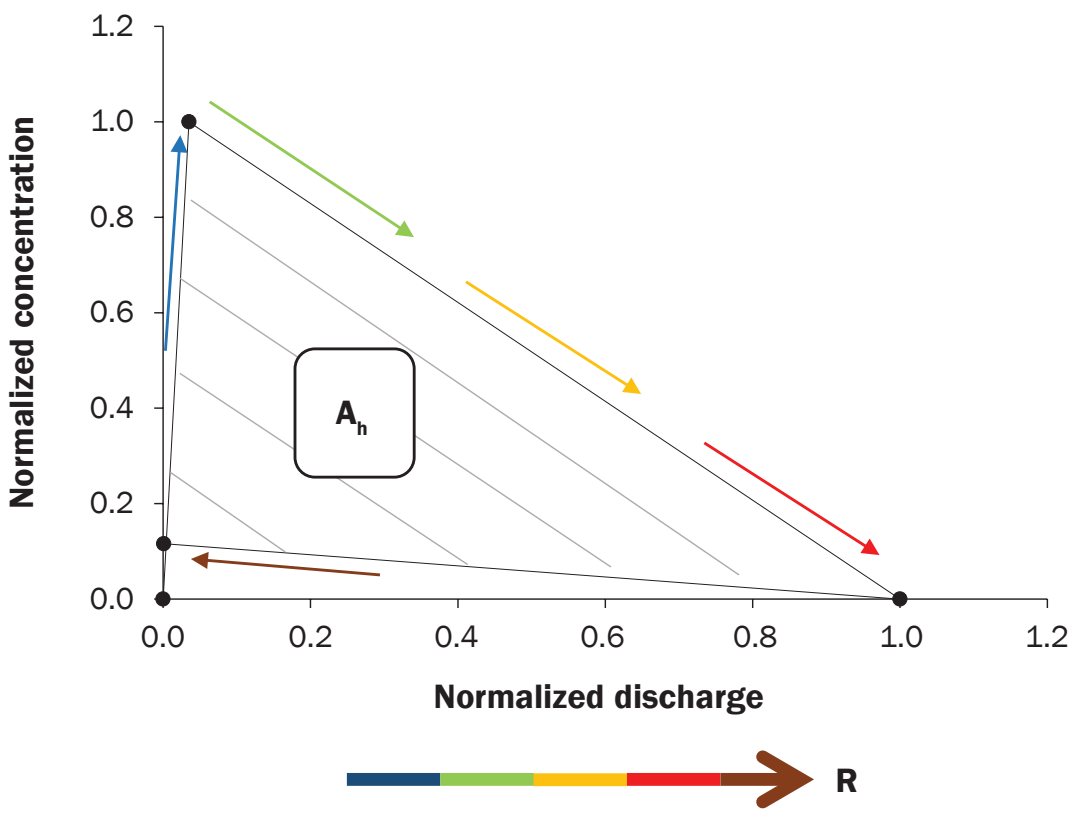

ible solute supply (source-limited) from a proximal source or intense discharge, whereas anticlockwise hysteresis (i.e., solute concentrations are higher at the peak or on the falling versus the rising hydrograph limb) suggests transport-limited systems, distal solute sources, or sources that are in deeper subsur- face zones. The relationship between the two hysteresis parameters and the recorded general discharge characteristics was analyzed using Pearson correlation analysis.

Finally, the variability of the two parameters $\left(\Delta \mathrm{C}_{\text {new }}[\%]\right.$ and $\left.\Delta \mathrm{R}[\%]\right)$ was presented in a two-dimensional plot of $\Delta \mathrm{C}_{\text {new }}(\%)$ versus $\Delta \mathrm{R}$ 
$(\%)$, in which four regions can be identified based on the solute trend (dilution or flushing) and the hysteresis loop rotation (clockwise or anticlockwise). More details on the two-dimensional plot can be found in Butturini et al. (2006) and Butturini et al. (2008).

\section{Results and Discussion}

Annual Dissolved Reactive Phosphorus Loads and Flow-Weighted Dissolved Reactive Phosphorus Concentration. Across plots and years, annual DRP loads measured in tile discharge ranged from 0 to $27 \mathrm{~g} \mathrm{ha}^{-1}$ (table 4). Also, in most instances, annual DRP loads from $\mathrm{P}$ source soils (plots 10,11, and 12) were an order of magnitude higher than annual DRP loads from $\mathrm{P}$ sink soils (remaining plots) but, in some years, plots 26 and 43 had DRP loads as high as $\mathrm{P}$ source soils (table 4). In general, these loads were low compared to average annual DRP loads of 15 to $99 \mathrm{~g} \mathrm{ha}^{-1}$ reported in the same study site for water years 2003 and 2005 (Hernandez-Ramirez et al. 2011). Nevertheless, nutrient loads lost from crop production systems are dependent on discharge (Williams et al. 2014). Therefore, a possible contributing factor for the differences in DRP loads for the treatments at the WQFS are the higher annual tile drain discharges of 25 to $81 \mathrm{~m}^{3}$ reported in Hernandez-Ramirez et al. (2011) compared to 10 to $63 \mathrm{~m}^{3}$ reported in Welikhe et al. (2020a).

Annual FDRP concentrations from the study plots ranged from 2 to $23 \mathrm{ug} \mathrm{L}^{-1}$ (table 4) and were lower than those observed in the same study site, i.e., 4 to 67 ug $\mathrm{L}^{-1}$, by Hernandez-Ramirez et al. (2011). Also, these FDRP concentrations were low compared to FDRP concentrations of 80 to $160 \mathrm{ug} \mathrm{L^{-1 }}$ and 58 to $231 \mathrm{ug} \mathrm{L}^{-1}$, reported for maize-soybean (Glycine max L.) rotations on a Bennington silt loam and a Pewamo clay loam in Ohio, and on mollisols in Illinois, respectively (King et al. 2015; Gentry et al. 2007). In the three previous study sites (WQFS, Ohio, and Illinois), P fertilizer was applied every other year at planting with maize to maintain optimum Bray P1/Mehlich 3P soil test levels for crop growth (King et al. 2015; HernandezRamirez et al. 2011; Gentry et al. 2007). In previous, related work, Welikhe et al. (2020a) showed that soils with negative SPSC values, which correspond to soils with $\mathrm{P}$ levels above the critical soil test P (STP) level of $22 \mathrm{mg}$ P $\mathrm{kg}^{-1}$ (table 2), were more prone to desorbing $\mathrm{P}$ and had a greater risk of losing DRP to the tile drains. Furthermore, the authors showed that $\mathrm{P}$ recommendations based on a build-up and maintenance approach lowered a soil's SPSC value below the threshold SPSC of 0 . Given neither King et al. (2015), HernandezRamirez et al. (2011), nor Gentry et al. (2007) reported SPSC and STP levels, direct comparisons between $\mathrm{P}$ status of soils in these studies versus the present study could not be made. Nevertheless, it is possible that the approach to $\mathrm{P}$ fertilizer management used by King et al. (2015), Hernandez-Ramirez et al. (2011), and Gentry et al. (2007) turned the soils into P sources as highlighted in Welikhe et al. (2020a). Soil type is another possible reason for the differences in FDRP concentrations lost to tile discharge among the studies. Pewamo clay loam is the major soil $(\sim 60 \%)$ in the tile drain contributing areas examined by King et al. 2015. Soils with high clay content have a greater risk of losing DRP to tile drains due to their tendency to develop preferential flow pathways (Simard et al. 2000), which could explain the higher FDRP losses in those soils. In the water years 2012 and 2013, FDRP concentrations > 20 ug $\mathrm{L}^{-1}$ were measured in tile discharge from plot 11 (table 4). Correll (1999) and Sharpley et al. (2003) reported that 20 ug $\mathrm{P} \mathrm{L}^{-1}$ was the concentration above which eutrophication was accelerated. However, all annual FDRP concentrations (table 4) were below USEPA's 50 ug $\mathrm{P} \mathrm{L}^{-1}$ acceptable water quality limit (USEPA 2002).

Discharge Events: General Description, Dissolved Reactive Phosphorus Loads, and Flow-Weighted Dissolved Reactive Phosphorus Concentrations. Based on our discharge event criteria, a total of 75 events (30 on P source soils [plots 10,11, and 12] and 45 on $\mathrm{P}$ sink soils [all other plots]) were selected (figure 2). Most of the events took place during fall (September 22 to December 20), winter (December 21 to March 19), and spring (March 20 to June 20). During summer (June 21 to September $21)$, there was no discharge in most tiles except for tiles 30, 43, and 44 in the summer of 2011. This discharge pattern is common in the region as a result of the interactions between precipitation, runoff, infiltration, and evapotranspiration (Gentry et al. 2007). Event discharge lasted an average of three or four days across tiles. Eight events lasted longer than the average duration $(>4$ days per tile). The $\mathrm{Q}$ and $\mathrm{Q}_{\max }$ varied between 145 and $7,993 \mathrm{~L} \mathrm{~d}^{-1}$ plot $^{-1}$, and 77 and 4,048 L $\mathrm{d}^{-1}$ plot $^{-1}$. Across events, $Q_{\text {ave }}$ ranged between
36 and 1,995 $\mathrm{L} \mathrm{d}^{-1}$ plot $^{-1}$. Forty-eight percent of the discharge events had $\mathrm{D}_{\text {rel }}$ values of $0 \%$, indicating an abrupt rising limb. Previous studies in the region reported similar findings where tile discharge peaked early and abruptly during storm events (Gentry et al. 2000; Schilling and Helmers 2008). Data for all general characteristics, DRP, and FDRP concentrations for each event can be found in supplementary materials (table S1).

Across all tiles, DRP loads and FDRP concentrations measured during selected discharge events ranged between 0 and $8.9 \mathrm{~g} \mathrm{P}$ $\mathrm{ha}^{-1}$ and 2 and $45 \mathrm{ug} \mathrm{P} \mathrm{L}^{-1}$, respectively (figure 2). There was no distinct trend of loss for both DRP load and FDRP in successive events in either $\mathrm{P}$ source or sink soils. However, when compared to $\mathrm{P}$ source soils, $\mathrm{P}$ sink soils had very low (some $0 \mathrm{~g} \mathrm{ha}^{-1}$ ) event DRP loads. Also, average FDRP concentrations from $\mathrm{P}$ source soils (with the exception of plot 10) were an order of magnitude higher than average FDRP concentrations from $\mathrm{P}$ sink soils. The event FDRP concentrations were below USEPA's 50 ug L ${ }^{-1}$ acceptable limit (USEPA 2002), with a few events (six events) having concentrations above the eutrophication acceleration limit 20 ug $\mathrm{P} \mathrm{L}^{-1}$ (Correll 1999; Sharpley et al. 2003). It is important to note that tile drainage can directly transport DRP to surface water bodies (e.g., stream, river, and lakes), bypassing the soil matrix where DRP could be sequestered (Smith et al. 2015; Reid et al. 2012). However, since most fields are at some distance from surface water bodies, discharge at the edge-of-field (drain outlets) must travel through drainage ditches, neighboring fields, or buffer areas where attenuation or amplification of the DRP losses could occur (Reid et al. 2018; Haygarth et al. 2005; McDowell et al. 2004).

Concentration-Discharge Relationships. The daily DRP flux had a linear relationship with daily discharge for both $\mathrm{P}$ source $\left(R^{2}=0.61\right)$ and $\operatorname{sink}\left(R^{2}=0.73\right)$ soils when data were log-transformed (figure 3$)$. The slope $(b=0.93)$ of the daily DRP load-discharge relationship for source soils had a 95\% confidence limit between 0.84 and 1.01 , indicating that $b$ was not significantly different from 1 and that DRP concentrations vary little compared to discharge (figure 3a). According to Godsey et al. (2009), this observation of chemostasis implies that there is a mechanism at play in the catchment that is buffering variations in solute concentrations over a large range of 


\section{Table 4}

Annual (water year) dissolved reactive phosphorus (DRP) loads and flow-weighted dissolved reactive phosphorus (FDRP) concentrations in tile discharge. Plots with negative Soil Phosphorus Storage Capacity values (phosphorus source soils) are in bold. Concentrations above which eutrophication is accelerated i.e., > 20 ug P L ${ }^{-1}$ (Correll 1999) are italicized. Refer to table 1 for description of treatments.

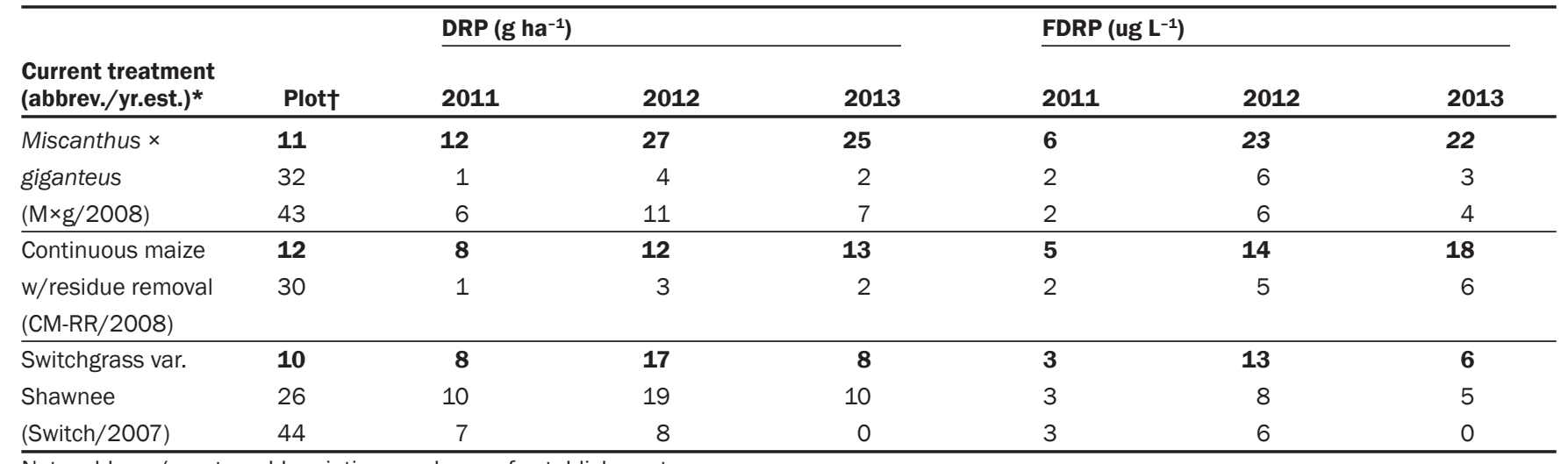

Note: abbrev./yr.est. = abbreviations and year of establishment.

discharge. Previous studies have shown that possible mechanisms include continuous weathering of bedrock for solutes such as magnesium $(\mathrm{Mg})$, sodium $(\mathrm{Na})$, and calcium (Ca) (Godsey et al. 2009), or the continuous release of legacy nutrients (e.g., $\mathrm{NO}_{3}^{-}$and P) in agricultural soils (Basu et al. 2010, 2011; Thompson et al. 2011). In MenezesBlackburn et al. (2016), P desorption rates were positively correlated $(r \geq 0.5 ; p \leq 0.01)$ with different STP concentrations in different tests, i.e., FeO strips, Olsen, oxalate, and $\mathrm{NaOH}-E D T A$, suggesting that increasing $\mathrm{STP}$ level was the main driver of $\mathrm{P}$ resupply from solid phase P into soil solution, and hence P bioavailability and lability. Further, Welikhe et al. (2020a) showed that once STP levels increase above an environmental STP threshold of $22 \mathrm{mg} \mathrm{kg}^{-1}$ (which corresponds to an SPSC threshold of 0 ), the soils turn into P source soils with an eight-fold greater risk of solid-phase $\mathrm{P}$ release into the soil solution. Sharpley et al. (1994) showed that these chronic transfers of solid phase $\mathrm{P}$ to runoff is symptomatic of long-term, repeated fertilizer and manure applications, which can lead to increases in solid phase $\mathrm{P}$ and ensuing desorption of $\mathrm{P}$ to runoff water. Thus, it is well-established that accumulated $\mathrm{P}$ in soils and DRP in surface and subsurface runoff are strongly tied (Vadas et al. 2005; Welikhe et al. 2020a). In this study, soils classified as P source soils were those with negative SPSC values. According to Nair et al. (2015), the magnitude of negative SPSC values are estimations of the loosely held legacy $\mathrm{P}$ stock in soils most prone to desorption into soil solution. Therefore, similar to other catchments with legacy nutrient stores, our P source soils acted as mass stores that continually buffered DRP concentrations against changing discharge. The chemostatic behavior in $\mathrm{P}$ source soils provides evidence to support the hypothesis of Williams et al. (2016) that P source soils could act as a source of labile $\mathrm{P}$ similar to surface-applied fertilizers, resulting

\section{Figure 2}

A bubble plot of flow-weighted dissolved reactive phosphorus (FWDRP) concentrations (ug $\mathrm{L}^{-1}$ ), total discharge $\left(\mathrm{L} \mathrm{d}^{-1}\right.$ plot $\left.^{-1}\right)$, and dissolved reactive phosphorus (DRP) loads ( $\mathrm{g} \mathrm{ha}^{-1}$ ) for the selected discharge events between October of 2010 and September of 2013 at the Water Quality Field Station (WQFS). The dashed line marks the concentration ( $20 \mathrm{ug} \mathrm{L}^{-1}$ ) above which eutrophication is accelerated (Correll 1999).

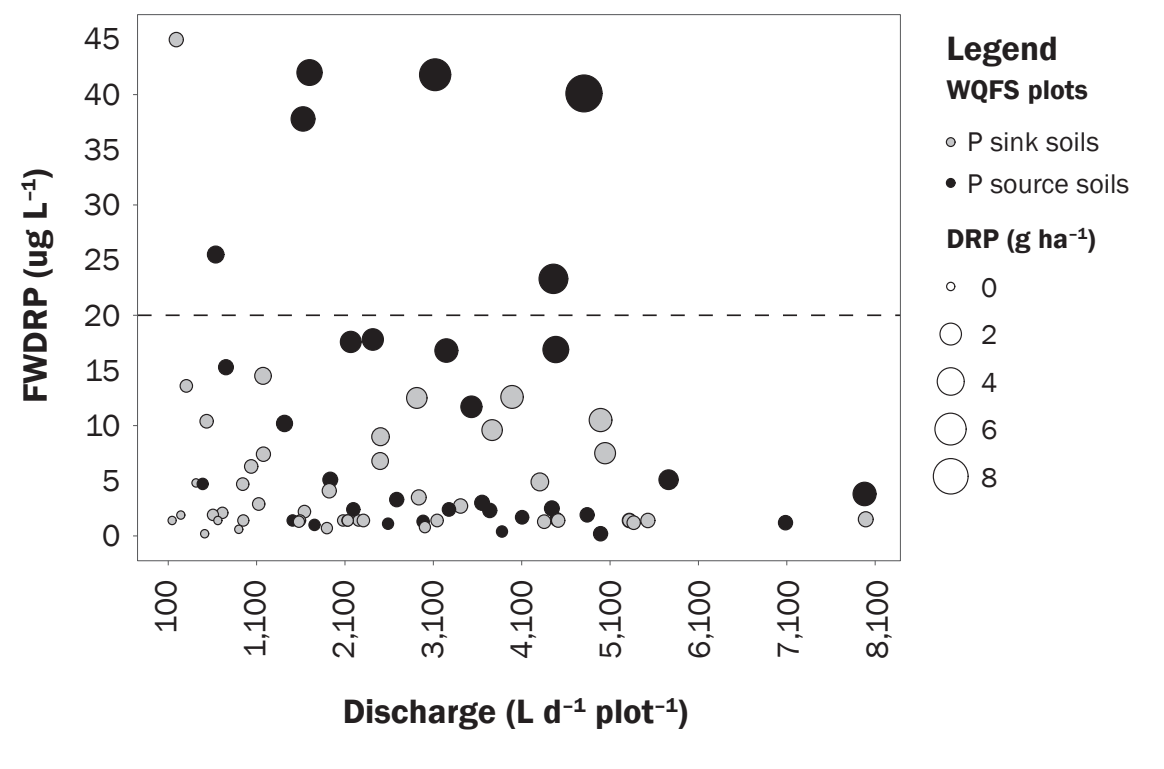

in continuous delivery of DRP to tile drains throughout the year.

The slope $(b=0.92)$ of the daily DRP concentrations-discharge relationship for $\mathrm{P}$ sink soils had a 95\% confidence limit between 0.87 and 0.96 , indicating that $b$ was significantly $<1$, and that lower DRP concentrations occurred in conjunction with high discharge totals (figure $3 \mathrm{~b}$ ). Although 


\section{Figure 3}

Daily dissolved reactive phosphorus (DRP) flux $\left(\mathrm{kg} \mathrm{ha}^{-1}\right)$ to discharge $(\mathrm{mm})$ relationship presented on a log-log scale for (a) phosphorus source soils and (b) phosphorus sink soils. Exponent $(b)$ and coefficient $(a)$ values are defined by equation 1 , and $R^{2}$ values were determined by linear regression on log transformed dissolved reactive phosphorus flux and discharge values.

(a)

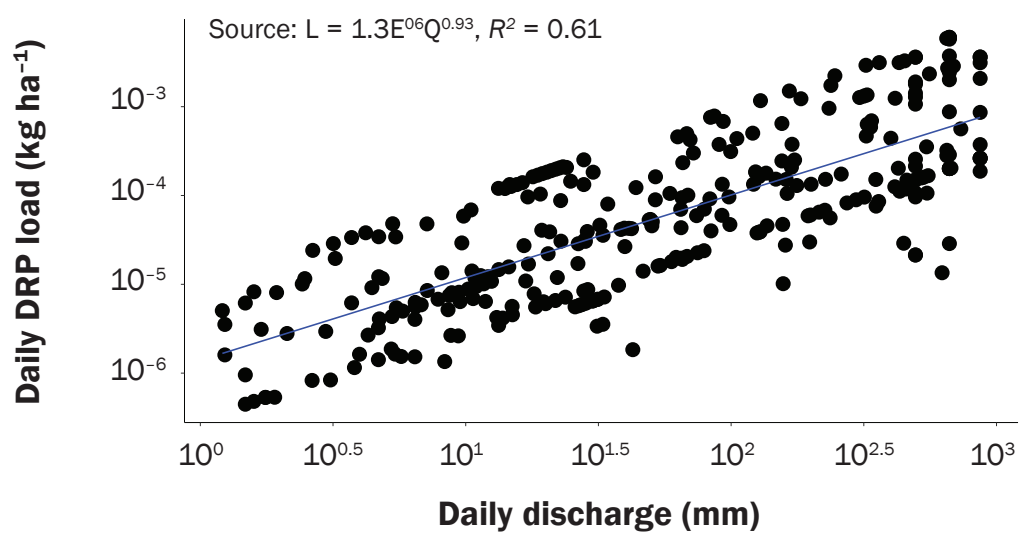

Legend

- Daily DRP Ioad

(b)

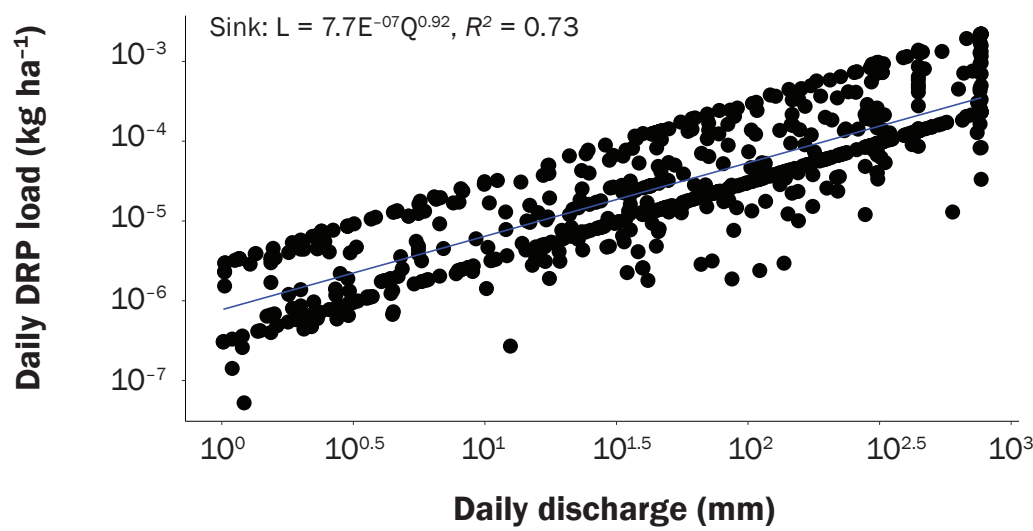

Legend

- Daily DRP load

this slope for sink soils was not significantly different from that of source soils $(b=0.93)$, the $\mathrm{C}-\mathrm{Q}$ relationship for sink soils suggests solute dilution with high discharge, which has been attributed to source limited or reaction rate-limited conditions (Godsey et al. 2009; Bieroza et al. 2018; Duncan et al. 2017a, 2017b). In P sink soils, the magnitude of positive SPSC values is an estimate of legacy P held in stable forms in these soils (Nair et al. 2015). Since desorption rates are much slower than sorption rates (MenezesBlackburn et al. 2016), the dilution behavior in sink soils is primarily controlled by this hysteretic behavior of $\mathrm{P}$ between the solid and liquid phase in soils.

At the event scale, a similar linear relationship between DRP flux from both P source and sink soils and discharge when log-transformed was observed $\left(R^{2}=0.64\right.$ and $R^{2}=$ 0.78 , respectively) (figure 4 ). However, the slopes $(b)$ of the log-log relationships highlighted a contrasting DRP dynamic at the event scale when compared to the daily scale. The slope $(b=0.88)$ of the event DRPdischarge relationship for source soils had a 95\% confidence limit between 0.75 and 0.99 , indicating that $b$ was significantly $<1$, i.e., a dilution effect (figure 4a). On the other hand, the slope $(b=0.94)$ of the event DRPdischarge relationship for sink soils had a 95\% confidence limit between 0.86 and 1.01 , indicating that $b$ was not significantly different from 1; i.e., chemostatsis (figure $4 b$ ).

Previous authors (Ruark et al. 2009; Duncan et al. 2017a, 2017b) have also reported contrasting C-Q patterns when data are analyzed at different time scales, e.g., daily, monthly, seasonal, or event time scales. These studies showed that the variation of $\mathrm{C}-\mathrm{Q}$ relationships across different time scales results from the different processes influencing $\mathrm{C}-\mathrm{Q}$ behavior at different temporal scales. Although it is possible that the event-scale dilution $(b<$ 1) observed in the P source soils could result from a single contribution of a high-source $\mathrm{P}$ pool that becomes increasingly exhausted throughout the event, the pervasive and persistent nature of legacy $\mathrm{P}$ in agricultural soils (Kleinman 2017) makes it unlikely that legacy stores become depleted on the timescale of an individual discharge event. On the other hand, the $b<1$ may be the result of a dilution of the DRP-rich water from P-rich surface soils by P-poor groundwater. Subsurface discharge water is composed of both shallow groundwater and precipitation water that has infiltrated through the soil and moved downward either by matrix or preferential flow (Stamm et al. 2002). Previous studies that used stable water isotopes and tracers to monitor movement of water into tile drains showed that the initial contributions into tile discharge most likely originated from surface soils and moved through active preferential flow paths (Greve et al. 2012; Williams et al. 2016). The latter studies further showed that as the event progressed and the soil matrix neared saturation, tile discharge transitioned from predominantly preferential flow (event water) to a mixture of preferential flow, matrix flow, and shallow groundwater (Greve et al. 2012; Williams et al. 2016). Even though water movement and mixing was not monitored in this study, the occurrence of lower DRP concentrations in conjunction with high discharge events suggests DRP concentrations may have been diluted by matrix and shallow groundwater that are poor in P. This interpretation is supported by Williams et al. (2016), who observed that elevated DRP concentrations in tile discharge coincided with peak event water contribution from preferential flow pathways before the waters, i.e., preferential and matrix flow, mixed along the 
flow pathway. Additionally, the effect of water table rise and antecedent soil moisture (both not measured in this study) on hysteresis patterns was documented by Macrae et al. (2010) and Wagner et al. (2008) in their $\mathrm{NO}_{3}-\mathrm{N}$ study where, instead of a solute dilution, they observed solute flushing (mobilization). With $\mathrm{NO}_{3}-\mathrm{N}$ and unlike with $\mathrm{P}$, which is not highly mobile and easily vertically distributed in soils (Baker et al. 2017), rising water tables mobilized $\mathrm{NO}_{3}-\mathrm{N}$ that is well-distributed in the soil matrix and is also found in high concentrations in shallow groundwater. In contrast, the chemostatic behavior $(b=1)$ observed at the event scale in sink soils suggests that these surface soils are just as $\mathrm{P}$ poor as matrix and shallow groundwater. Since the stable forms of $\mathrm{P}$ in $\mathrm{P}$ sink soils are not readily desorbed (Nair et al. 2015), water leaching through a $\mathrm{P}$ sink surface soil may have a similar and low $\mathrm{P}$ concentration as that of matrix and groundwater. Based on these results, the proposed conceptual models illustrating DRP loss in $\mathrm{P}$ source and $\mathrm{P}$ sink soils are presented in figure 5 .

Our results from both timescales highlight the importance of P-rich surface soils and hydrological connectivity for DRP loss to tile drains. The continuous release of DRP from $\mathrm{P}$ source soils highlights how legacy $\mathrm{P}$ continues to undermine $\mathrm{P}$ mitigation efforts. Unfortunately, phytomining (growing and harvesting crops without $\mathrm{P}$ fertilization) takes decades or longer to draw down P (McCollum 1991; Schärer et al. 2007; Sharpley and Rekolainen 1997). On the other hand, there are a few timelier and cost-effective materials arising as waste streams from various processes, which can be used to sequester $\mathrm{P}$ from $\mathrm{P}$-rich soils. These materials include fluidized gas desulfurization (FGD) gypsum, red muds, crushed concrete, Fe gels, etc. (Kleinman et al. 2019; Murphy and Stevens 2010; Egemose et al. 2012; Chardon et al. 2012; Weng et al. 2012). Among these amendments, FGD gypsum has gained traction due to its added benefit of acting as a source of sulfur (S), and because it can be used for the treatment of sea-salt impacted soils (Murphy and Stevens 2010). However, cost and possible adverse effects from the use of the remaining $\mathrm{P}$ amendments has hindered their adoption (Kleinman et al. 2019). Also, given macropores are generally believed to be the major pathway through which DRP is transported to tile drains, some studies recommend tillage to disrupt

\section{Figure 4}

Event dissolved reactive phosphorus (DRP) flux $\left(\mathrm{kg} \mathrm{ha}^{-1}\right)$ to discharge $(\mathrm{mm})$ relationship presented on a log-log scale for (a) phosphorus source soils and (b) phosphorus sink soils. Exponent $(b)$ and coefficient $(a)$ values are defined by equation 1 , and $R^{2}$ values were determined by linear regression on log transformed dissolved reactive phosphorus flux and discharge values.

(a)

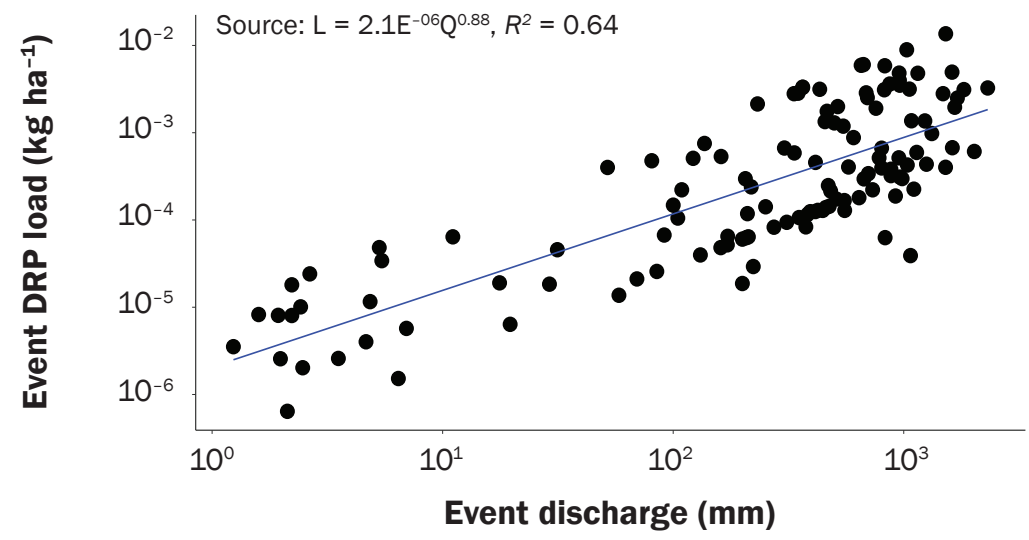

Legend

- Event DRP load

(b)

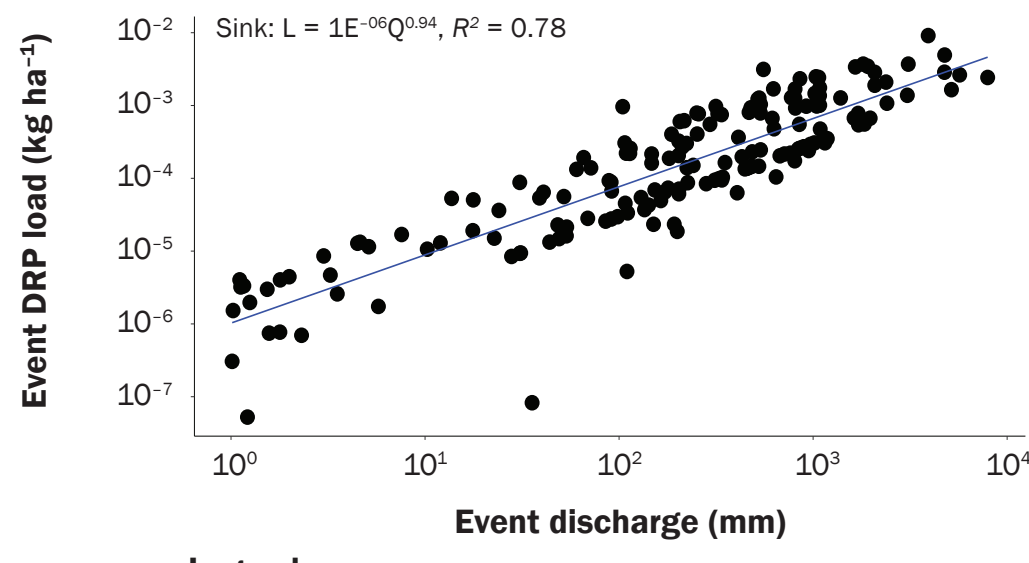

\section{Legend}

- Event DRP load

macropore flow pathways and decrease hydrological connectivity (Williams et al. 2016). Although tillage could potentially reduce DRP losses through tile discharge, it could also increase particulate $\mathrm{P}$ losses (Verbree et al. 2010), therefore it may not be a suitable conservation practice.

Hysteresis Patterns. Pearson's correlation analysis (combined data for $\mathrm{P}$ source and $\mathrm{P}$ sink soils) of discharge characteristics descriptors of C-Q hysteresis identified significant relationships among $\Delta \mathrm{R}, \mathrm{Q}$, and $\mathrm{D}_{\text {rel }}$ (table 5$) . \Delta \mathrm{R}$ was positively correlated to $\mathrm{Q}(p<0.05)$ and $\mathrm{D}_{\text {rel }}(p<0.01)$, suggesting that an increase in $\mathrm{Q}$ and $\mathrm{D}_{\text {rel }}$ would lead to a shift in loop trajectories from anticlockwise to clockwise. This observation has been reported in previous studies in which DRP anticlockwise loops were mostly associated with low discharge events (Williams et al. 2018; Bowes et al. 2005; Chow et al. 2017; Bieroza and Heathwaite 2015). The $\Delta \mathrm{C}$ was not significantly correlated with any of the discharge event characteristics. Figure 6 shows a plot of $\Delta \mathrm{C}_{\text {new }}(\%)$ and $\Delta \mathrm{R}(\%)$ that summarizes $\mathrm{C}-\mathrm{Q}$ hysteresis loop types of the DRP from sink and source soils during the selected discharge events. Potential nutrient 


\section{Figure 5}

(a) A proposed conceptual model illustrating dissolved reactive phosphorus (DRP) loss in tile drained fields from phosphorus (P) source soils where (i) discharge at the start of the event when $P$ rich preferential flow (event water) from the surface rapidly flows to tile drains, (ii) discharge during the event when $P$ rich event water is mixed with $P$ poor water from the soil matrix and shallow groundwater, resulting in an overall dilution, and (iii) when the discharge recedes, contributions from soil matrix and shallow groundwater are absent, event water with high $P$ concentrations continues. (b) A proposed conceptual model illustrating DRP loss in tile drained fields from P sink soils where (i) discharge at the start of the event when P poor preferential flow (event water) from the surface rapidly flows to tile drains, (ii) discharge during the event when P poor waters (preferential, matrix, and shallow groundwater) mix, and (iii) when soil matrix and shallow groundwater recede, event water with low $\mathrm{P}$ concentrations continues.

(a)

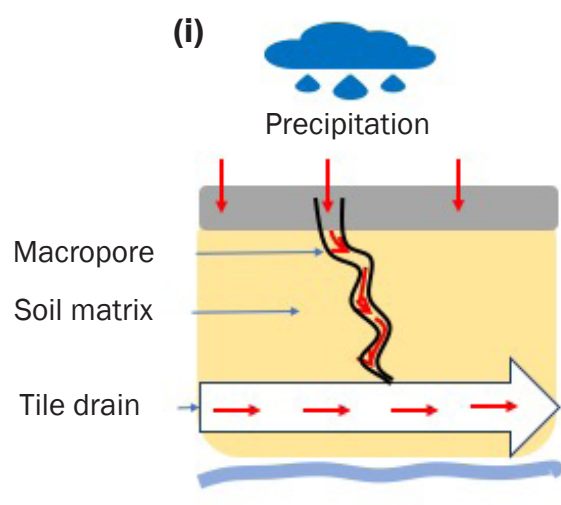

(b)

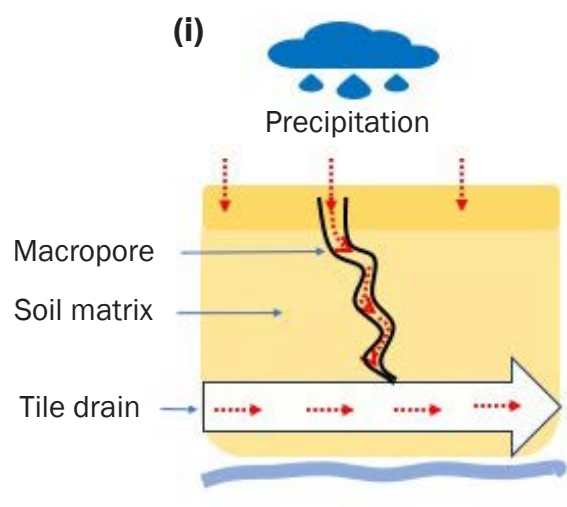

(ii)

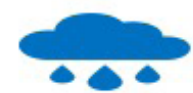

Precipitation

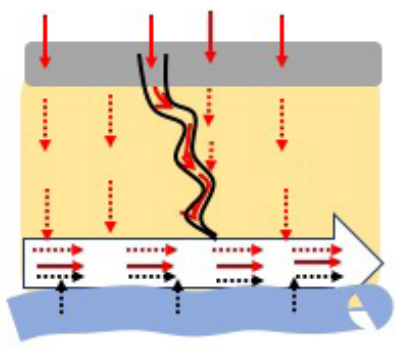

(ii)

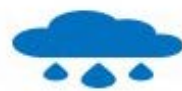

Precipitation

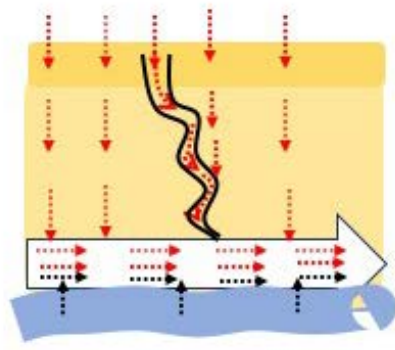

(iii)

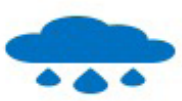

Precipitation

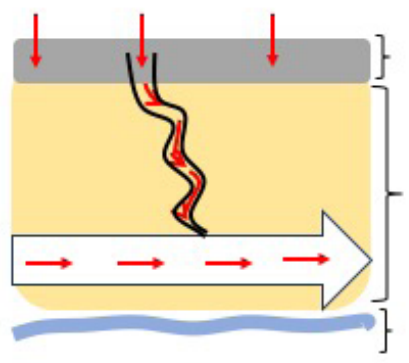

Surface soils (P rich)

P poor

subsurface soil

P poor groundwater

\section{Legend}

$\longrightarrow$ High DRP concentrations with discharge from surface soils.

...... Low DRP concentrations with discharge from surface soils.

...... Low DRP concentrations with discharge from shallow groundwater.

sources and delivery pathways to surface water are usually inferred from C-Q hysteresis loops where clockwise hysteresis infers proximal sources with exhaustible solute supply or intense discharge, and anticlockwise hysteresis infers distal sources or transport-limited systems (Bowes et al. 2015). However, as noted by Williams et al. (2018), interpretation of hysteresis loops in tile-drained systems is more complex as even distant sources are directly connected to streams by tile drains.

The use of low resolution data (daily sampling) did not accurately capture the variation in DRP concentrations $\left(\Delta \mathrm{C}_{\text {new }}\right.$ $[\%])$. For example, for some events, initial $Q$ was also $\mathrm{Q}_{\max }$ in a discharge event, therefore, $\mathrm{C}_{\mathrm{i}}=\mathrm{C}_{\mathrm{s}}$, resulting in discharge events whose solute trend (flushing or dilution) could not be determined given they plotted on the $y$ $=0$ line (figure 6). These discharge events included $42 \% \quad(30 \%$ anticlockwise, $12 \%$ clockwise) and 25\% (18\% anticklockwise, $7 \%$ clockwise) of events in $\mathrm{P}$ source and sink soils, respectively.

Of the remaining discharge events, our results show that hysteresis behavior of events in $\mathrm{P}$ source soils was variable with all of the following behaviors exhibited: anticlockwise with dilution (21\%), anticlockwise with flushing (7\%), clockwise with dilution (6\%), clockwise with flushing (9\%), and no hysteresis behavior (15\%), respectively. According to Williams et al. (2018) this variability in hysteresis behavior suggests that multiple flow pathways and transport mechanisms are involved in DRP loss to tile drains. The predominant anticlockwise and dilution pattern of events in $\mathrm{P}$ source soils (region $\mathrm{C}$ of figure 6) has two implications. First, tile drains facilitate the rapid transport of DRP from $\mathrm{P}$ rich surface soils and the contribution of event 
water to tile discharge (Vidon and Cuadra 2011; Williams et al. 2016). Second, the mixing between preferential water, matrix water, and shallow groundwater may delay the peak in DRP concentration; thus a dilution of high DRP concentrations when waters mix results in anticlockwise hysteresis (high DRP concetrations on the falling limb versus the rising limb of the hydrograph) (Williams et al. 2018). The majority dilution pattern of events in $\mathrm{P}$ source soils is consistent with our results $(b<1)$, from the C-Q slope analysis at the event scale $(b<1$; figure $4 a)$. It reinforces our interpretation of the slopes of the $\mathrm{C}-\mathrm{Q}$ relationships where the initial, high DRP concentrations in event water progressively mixes with lower DRP concentrations in shallow groundwater, resulting in a dilution as discharge approaches its peak. The anticlockwise hysteresis (illustration in region $\mathrm{C}$ of figure 6) further shows that the dilution pattern reverses as discharge recedes, with soil matrix water and shallow groundwater progressively becoming disconnected from the tile drains, whereas event water from P-rich surface soils remains hydrologically connected through preferential pathways. In contrast, during other events, insufficient rise of shallow groundwater around tiledrains may prevent the mixing of $\mathrm{P}$-rich and P-poor waters. This minimal mixing coupled with rapid transport of DRP and the contribution of event water to tile discharge, may result in clockwise hysteresis (high DRP concetrations on the rising limb versus the falling limb of the hydrograph) (Williams et al. 2018, 2016; Vidon and Cuadra 2011). Also, the positive correlations of $\Delta \mathrm{R}(\%)$ with $\mathrm{Q}$ and $\mathrm{D}_{\text {rel }}$ (table 5) show that the shift from anticlockwise to clockwise hysteresis may be the result of an increase in $Q$ and $D_{\text {rel }}$ Finally, the variation in DRP response could be the result of rapid exchanges between $\mathrm{P}$ pools due to sorption/desorption and biological processes under varying antecedent conditions (Williams et al. 2018). This variable hysteresis behavior and solute trend underscores the challenge of interpreting the contributing mechanisms to better manage DRP loss from P source soils in tile drained systems. However, we note that our results may be an artifact of low temporal resolution sampling. Events in $\mathrm{P}$ sink soils seemed to generally have no hysteresis or solute trend, i.e., $67 \%$ of the events were plotted at the origin. These results support the chemostatic $(b=1)$ finding in the event C-Q slope analy-

\section{Table 5}

Pearson correlation matrix between general discharge event characteristics and the $\Delta R(\%)$ and $\Delta \mathrm{C}(\%)$ parameters (combined data for phosphorus [P] source and $\mathrm{P}$ sink soils).

\begin{tabular}{|c|c|c|c|c|c|c|c|c|}
\hline & ED & $\Delta t$ & $\mathbf{Q}$ & $\mathbf{Q}_{\text {ave }}$ & $\mathbf{Q}_{\max }$ & $D_{\text {rel }}$ & $\Delta \mathrm{R}(\%)$ & $\Delta \mathbf{C}_{\text {new }}(\%)$ \\
\hline ED & 1.00 & & & & & & & \\
\hline$\Delta t$ & 0.10 & 1.00 & & & & & & \\
\hline $\mathbf{Q}$ & 0.10 & 0.01 & 1.00 & & & & & \\
\hline $\mathbf{Q}_{\text {ave }}$ & 0.08 & 0.18 & -0.10 & 1.00 & & & & \\
\hline $\mathbf{Q}_{\max }$ & 0.15 & 0.12 & -0.14 & 0.93 & 1.00 & & & \\
\hline $\mathbf{D}_{\text {rel }}$ & -0.06 & -0.08 & -0.12 & 0.11 & 0.09 & 1.00 & & \\
\hline$\Delta R(\%)$ & -0.06 & 0.13 & 0.23 & -0.01 & -0.15 & 0.30 & 1.00 & \\
\hline$\Delta C(\%)$ & 0.00 & -0.08 & -0.06 & -0.04 & -0.07 & -0.19 & -0.23 & 1.00 \\
\hline
\end{tabular}

Notes: Correlation is significant at $p<0.001$ level for bold italic numbers, at $p<0.01$ for bold numbers, at $p<0.05$ for bold, italic, and underlined numbers. $E D=$ event duration. $\Delta t=$ days since previous event. $Q=$ total discharge. $Q_{\text {ave }}=$ average event discharge. $Q_{\max }=$ peak event discharge. $D_{\text {rel }}=$ relative length (days) of the rising limb. $\Delta R(\%)=$ rotational pattern of hysteresis loops. $\Delta \mathrm{C}(\%)=$ solute trends (neutral, dilution, or flushing).

\section{Figure 6}

Plot of relative change in solute concentrations $\left(\Delta \mathrm{C}_{\text {new }}\right.$ [\%]) versus change in rotational patterns $(\Delta \mathrm{R}[\%])$ for the $\mathrm{C}-\mathrm{Q}$ hysteresis loops of dissolved reactive phosphorus (DRP). The $i, j$, and $k$ terms in the plot labels correspond to ith season (winter [W], spring [Sp], summer [Su], and fall [F]) in a water year (2011, 2012, and 2013), the $j$ th plot at the Water Quality Field Station ( $\mathrm{P}_{10}, \mathrm{P}_{11}, \mathrm{P}_{12}, \mathrm{P}_{26}, \mathrm{P}_{30}, \mathrm{P}_{32}, \mathrm{P}_{43}$, and $\mathrm{P}_{44}$ ), and the $k$ th discharge event for the specified plot. Supplementary table $\mathrm{S}_{1}$ provides detailed information on discharge events. Illustrations of the typical $C-Q$ relationships ( $C$, dashed blue line; $Q$, continuous brown line) are presented for each of the regions $A$ through $D$ of the $\Delta C_{\text {new }}(\%)$ versus $\Delta R$ plot. $A$ few events in phosphorus source soils showed clockwise hysteresis.

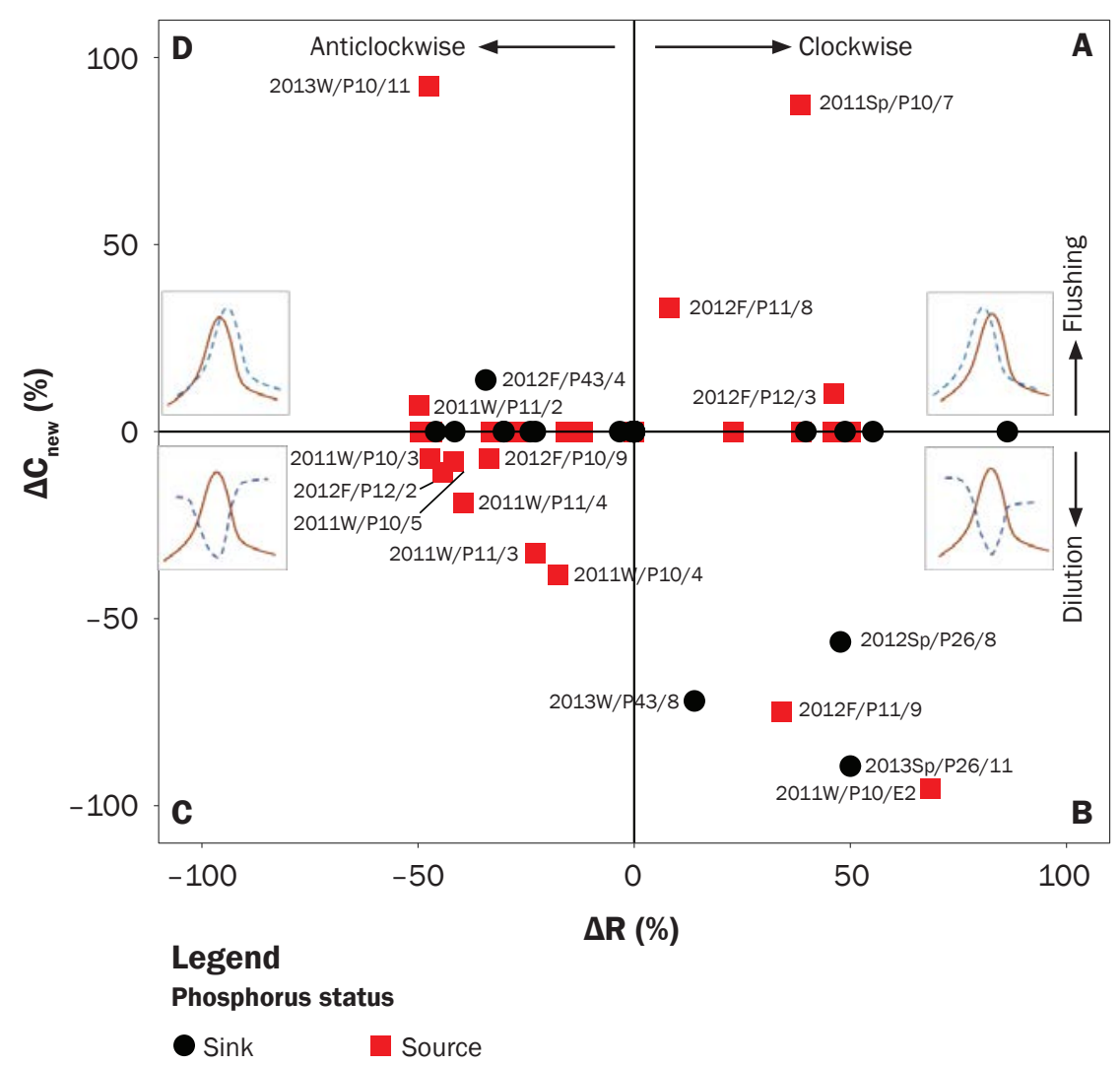


ses of sink soils. Among the remaining events whose solute trends were identified, $2 \%$ and $6 \%$ were anticlockwise with flushing and clockwise with dilution, respectively.

Even though tile drains are a major pathway for DRP loss as shown in this study and others (Welikhe et al. 2020a; Gentry et al. 2007; Macrae et al. 2007; Gelbrecht et al. 2005), our results suggest that the water table dynamics during discharge events, soil $\mathrm{P}$ status, soil $\mathrm{P}$ stratification, the amount of discharge, and the number of days it takes to reach peak discharge, also control nutrient delivery and hysteresis patterns. Also, there are other factors not accounted for in our study that may influence DRP-Q dynamics and are worthy of future study. For example, detailed assessments of the influence of crop residues in no-till systems on DRP concentrations in tile effluent are needed. Numerous studies have reported that DRP loss can be greater in runoff (surface and subsurface) from no-till or conservation till systems than from conventional till systems (Bundy et al. 2001; Daverede et al. 2003; Tiessen et al. 2010; Liu et al. 2014). Earlier studies attributed the increased DRP losses to nutrient stratification at the soil surface in conservation and no-till systems compared to conventional systems (Bundy et al. 2001; Daverede et al. 2003). However, recent literature also suggests that the crop residues remaining on the soil surface in conservation and no-till systems release $\mathrm{P}$ when exposed to multiple freeze-thaw cycles in cold climates from late fall to early spring, thus acting as an additional source of DRP (Liu et al. 2019, 2014; Lozier et al. 2017).

\section{Summary and Conclusions}

A series of DRP C-Q relationships were examined within the context of soil $\mathrm{P}$ status to elucidate solute pathways and investigate key components driving nutrient delivery in no-till tile drained systems. Our results showed that dynamics of DRP loss from $\mathrm{P}$ source and $\mathrm{P}$ sink soils in tile drained systems are different. Results from the daily C-Q slopes suggest that the differences in solute behavior and export during discharge events were regulated by solute reactivity, availability, and mobilization from surface soils. At the event scale, results from both C-Q slopes and hysteresis indices suggest that DRP behavior and export were regulated by DRP availability in surface soils, and, potentially, the degree of mixing between event water, matrix water, and rising shallow groundwater. Also, changes in discharge event characteristics including $\mathrm{Q}$ and $\mathrm{D}_{\text {rel }}$ influenced DRP hysteresis. Despite the complex hysteresis behavior observed, findings suggest that mitigation of DRP loss from P source soils in tile-drained systems should involve both nutrient management practices aimed at $\mathrm{P}$ draw down (e.g., phytomining) and $\mathrm{P}$ sequestration. Even though tillage has been proposed as a way to reduce hydrological connectivity between $\mathrm{P}$ rich surface soils and tile drains, it has not gained traction due to concerns over potential adverse impacts on particulate $\mathrm{P}$ loss. To avoid conversion of $\mathrm{P}$ sink soils to $\mathrm{P}$ source soils, $4 \mathrm{R}$ nutrient management practices with an emphasis on "feeding" the crop not the soil will be needed. Due to low temporal resolution data, the current study only focused on single peak events; thus, future research analyzing DRP dynamics in both single and multipeak discharge events and at higher temporal resolution is needed to increase understanding of P-loss patterns, inform nutrient management recommendations, and, ultimately, improve water quality.

\section{Supplementary Material}

Supplementary material for this article is available in the online journal at https://doi.org/10.2489/jswc.2022.00012.

\section{Acknowledgements}

The authors would like to thank Nicole De Armond (Water Quality Field Station [WQFS] Manager, Department of Agronomy, Purdue University) for her efforts in maintaining the WQFS, collecting and maintaining tile drain effluent samples and soil samples, and managing the legacy data for use in this study. This work was supported by the USDA National Institute of Food and Agriculture (NIFA) National Research Initiative Managed Ecosystem Program grant (Award Number 2008-35101-19152), US DOE 2009 North Central Sun Grant Competitive Grants Program (Award Number DE-FG36-08GO88073), USDA NIFA Bioenergy CAP grant (Award Number 2011-68005-30411), and the $4 \mathrm{R}$ Research Fund of the Foundation for Agronomic Research (Project Number 2015-USA-4RN45) with additional support from a Purdue University Ecological Sciences and Engineering Lynn Fellowship and the Estate of Orpha M.Wickersham.

\section{References}

Baker, D.B., L.T. Johnson, R.B. Confesor, and J.P. Crumrine. 2017. Vertical stratification of soil phosphorus as a concern for dissolved phosphorus runoff in the Lake Erie basin. Journal of Environmental Quality 46(6):12871295. https://doi.org/10.2134/jeq2016.09.0337.
Basu, N.B., G. Destouni, J.W. Jawitz, S.E. Thompson, N.V. Loukinova, A. Darracq, and P.S.C. Rao. 2010. Nutrient loads exported from managed catchments reveal emergent biogeochemical stationarity. Geophysical Research Letters 37(23):1-5. https://doi. org/10.1029/2010GL045168.

Basu, N.B., S.E.Thompson, and P.S.C. Rao. 2011. Hydrologic and biogeochemical functioning of intensively managed catchments: A synthesis of top-down analyses. Water Resources Research 47(10):1-12. https://doi. org/10.1029/2011WR010800.

Beauchemin, S., R.R. Simard, and D. Cluis. 1998. Forms and concentration of phosphorus in drainage water of twenty-seven tile-drained soils. Journal of Environmental Quality 27(3):721-728. https://doi.org/10.2134/ jeq1998.00472425002700030033x.

Bende-Michl, U., K. Verburg, and H.P. Cresswell. 2013. High-frequency nutrient monitoring to infer seasonal patterns in catchment source availability, mobilisation and delivery. Environmental Monitoring and Assessment 185(11):9191-9219. https://doi.org/10.1007/ s10661-013-3246-8.

Bieroza, M.Z., and A.L. Heathwaite. 2015. Seasonal variation in phosphorus concentration-discharge hysteresis inferred from high-frequency in situ monitoring. Journal of Hydrology 524:333-347. https://doi.org/10.1016/j. jhydrol.2015.02.036.

Bieroza, M.Z., A.L. Heathwaite, M. Bechmann, K. Kyllmar, and P. Jordan. 2018. The concentration-discharge slope as a tool for water quality management. Science of the Total Environment 630:738-749. https://doi. org/10.1016/j.scitotenv.2018.02.256.

Bowes, M.J., W.A. House, R.A. Hodgkinson, and D.V. Leach. 2005. Phosphorus-discharge hysteresis during storm events along a river catchment: The River Swale, UK. Water Research 39(5):751-762. https://doi. org/10.1016/j.watres.2004.11.027

Bowes, M.J., H.P. Jarvie, S.J. Halliday, R.A. Skeffington, A.J. Wade, M. Loewenthal, and E.J. Palmer-Felgate. 2015. Characterising phosphorus and nitrate inputs to a rural river using high-frequency concentration-flow relationships. Science of the Total Environment 511:608620. https://doi.org/10.1016/j.scitotenv.2014.12.086.

Butturini,A., M. Alvarez, S. Bernał, E.Vazquez, and F. Sabater. 2008. Diversity and temporal sequences of forms of DOC and $\mathrm{NO}_{3}{ }^{-}$discharge responses in an intermittent stream: Predictable or random succession? Journal of Geophysical Research: Biogeosciences 113(3):1-10. https://doi.org/10.1029/2008JG000721.

Butturini,A., G. Francesc, L. Jérôme,V.Eusebi, and S. Francesc. 2006. Cross-site comparison of variability of DOC and nitrate $\mathrm{C}-\mathrm{Q}$ hysteresis during the autumn-winter period in three Mediterranean headwater streams: A synthetic approach. Biogeochemistry 77(3):327-349. https://doi. org/10.1007/s10533-005-0711-7.

Chanat, J.G., K.C. Rice, and G.M. Hornberger. 2002. Consistency of patterns in concentration-discharge 
plots. Water Resources Research 38(8):22-1-22-10. https://doi.org/10.1029/2001wr000971.

Chardon, W.J., J.E. Groenenberg, E.J.M. Temminghoff, and G.F. Koopmans. 2012. Use of reactive materials to bind phosphorus. Journal of Environmental Quality 41(3):636-646. https://doi.org/10.2134/jeq2011.0055.

Chow, M.F., J.C. Huang, and F.K. Shiah. 2017. Phosphorus dynamics along river continuum during typhoon storm events. Water (Switzerland) 9(7):1-15. https://doi. org/10.3390/w9070537.

Correll, D.L. 1999. Phosphorus: A rate limiting nutrient in surface waters. Poultry Science 78(5):674-682. https:// doi.org/10.1093/ps/78.5.674.

Diamond, J.S. 2013. Concentration-discharge relationships for streams and rivers in florida: Patterns and controls. Master's thesis. University of Florida. https://ufdc.ufl. edu/UFE0045545/00001.

Djodjic, F., L. Bergström, and B. Ulén. 2006. Phosphorus losses from a structured clay soil in relation to tillage practices. Soil Use and Management 18(2):79-83. https://doi.org/10.1111/j.1475-2743.2002.tb00223.x.

Djodjic, F., L. Bergström, B. Ulén, and A. Shirmohammadi. 1999. Mode of transport of surface-applied phosphorus-33 through a clay and sandy soil. Journal of Environmental Quality 28(4):1273-1282. https://doi. org/10.2134/jeq1999.00472425002800040031x.

Duncan, J.M., L.E. Band, and P.M. Groffman. 2017a.Variable nitrate concentration-discharge relationships in a forested watershed. Hydrological Processes 31(9):18171824. https://doi.org/10.1002/hyp.11136.

Duncan, J.M., C. Welty, J.T. Kemper, P.M. Groffman, and L.E. Band. 2017b. Dynamics of nitrate concentrationdischarge patterns in an urban watershed. Water Resources Research 53(8):7349-7365. https://doi. org/10.1002/2017WR020500.

Egemose, S., M.J. Sønderup, M.V. Beinthin, K. Reitzel, C.C. Hoffmann, and M.R. Flindt. 2012. Crushed concrete as a phosphate binding material: A potential new management tool. Journal of Environmental Quality 41(3):647-653. https://doi.org/10.2134/jeq2011.0134.

Gelbrecht, J., H. Lengsfeld, R. Pöthig, and D. Opitz. 2005. Temporal and spatial variation of phosphorus input, retention and loss in a small catchment of NE Germany. Journal of Hydrology 304(1-4):151-165. https://doi. org/10.1016/j.jhydrol.2004.07.028.

Gentry, L.E., M.B. David, T.V. Royer, C.A. Mitchell, and K.M. Starks. 2007. Phosphorus transport pathways to streams in tile-drained agricultural watersheds. Journal of Environment Quality 36(2):408. https://doi. org/10.2134/jeq2006.0098.

Gentry, L.E., M.B. David, K.M. Smith-Starks, and D.A Kovacic. 2000. Nitrogen fertilizer and herbicide transport from tile drained fields. Journal of Environmental Quality 29(1):232-240. https://doi.org/10.2134/ jeq2000.00472425002900010030x.

Godsey, S.E., J.W. Kirchner, and D.W. Clow. 2009 Concentration-discharge relationships reflect chemostatic characteristics of US catchments. Hydrological Processes 2309(May):2300-2309. https:// doi.org/10.1002/hyp.

Greve, A.K., M.S. Andersen, and R.I. Acworth. 2012 Monitoring the transition from preferential to matrix flow in cracking clay soil through changes in electrical anisotropy. Geoderma 179-180:46-52. https://doi. org/10.1016/j.geoderma.2012.02.003.

Hernandez-Ramirez, G., S.M. Brouder, M.D. Ruark, and R.F. Turco. 2011. Nitrate, phosphate, and ammonium loads at subsurface drains: Agroecosystems and nitrogen management. Journal of Environmental Quality 40(4):1229-1240. https://doi.org/10.2134/ jeq2010.0195.

Hoagland, B., T.A. Russo, X. Gu, L. Hill, J. Kaye, B. Forsythe, and S.L. Brantley. 2017. Hyporheic zone influences on concentration-discharge relationships in a headwater sandstone Stream. Water Resources Research 53:46434667. https://doi.org/10.1002/2016WR019717.

Jarvis, N.J. 2007. A review of non-equilibrium water flow and solute transport in soil macropores: Principles, controlling factors and consequences for water quality. European Journal of Soil Science 58(3):523-546. https://doi.org/10.1111/j.1365-2389.2007.00915.x.

Johnson, N.M., G.E. Likens, F.H. Bormann, D. Fisher, D.W Fisher, and R.S. Pierce. 1969. A working model for the variation in stream water chemistry at the Hubbard Brook Experimental Forest, New Hampshire. Water Resources Research 5(6):1353-1363. https://doi. org/10.1029/WR005i006p01353.

King, K.W., N.R. Fausey, and M.R. Williams. 2014 Effect of subsurface drainage on streamflow in an agricultural headwater watershed. Journal of Hydrology 519(PA):438-445. https://doi.org/10.1016/j. jhydrol.2014.07.035.

King, K.W., M.R. Williams, and N.R. Fausey. 2015 Contributions of systematic tile drainage to watershedscale phosphorus transport. Journal of Environment Quality 44(2):486. https://doi.org/10.2134/ jeq2014.04.0149.

Kinley, R.D., R.J. Gordon, G.W. Stratton, G.T. Patterson, and J. Hoyle. 2007. Phosphorus losses through agricultural tile drainage in Nova Scotia, Canada. Journal of Environmental Quality 36(2):469-477. https://doi. org/10.2134/jeq2006.0138.

Kleinman, P.J.A. 2017. The persistent environmental relevance of soil phosphorus sorption saturation. Current Pollution Reports 3(2):141-150. https://doi. org/10.1007/s40726-017-0058-4.

Kleinman, P.J.A., R.M. Fanelli, R.M. Hirsch, A.R. Buda, Z.M. Easton, L.A. Wainger, and G.W. Shenk. 2019 Phosphorus and the Chesapeake Bay: Lingering issues and emerging concerns for agriculture. Journal of Environmental Quality 48(5):1191-1203. https://doi. org/10.2134/jeq2019.03.0112.

Lawler, D.M., G.E. Petts, I.D.L. Foster, and S. Harper. 2006 Turbidity dynamics during spring storm events in an urban headwater river system: The Upper Tame, West Midlands, UK. The Science of the Total Environment 360(1-3):109-126. https://doi.org/10.1016/j. scitotenv.2005.08.032

Lloyd, C.E.M., J.E. Freer, P.J. Johnes, and A.L. Collins. 2016a. Technical note: Testing an improved index for analysing storm discharge-concentration hysteresis. Hydrology and Earth System Sciences 20(2):625-632. https://doi. org/10.5194/hess-20-625-2016.

Lloyd, C.E.M., J.E. Freer, P.J. Johnes, and A.L. Collins. 2016b. Using hysteresis analysis of high-resolution water quality monitoring data, including uncertainty, to infer controls on nutrient and sediment transfer in catchments. The Science of the Total Environment 543:388-404. https:// doi.org/10.1016/j.scitotenv.2015.11.028.

Macrae, M.L., M.C. English, S.L. Schiff, and M. Stone. 2007. Intra-annual variability in the contribution of tile drains to basin discharge and phosphorus export in a first-order agricultural catchment. Agricultural Water Management 92(3):171-182. https://doi. org/10.1016/j.agwat.2007.05.015.

Macrae, M.L., M.C. English, S.L. Schiff, and M. Stone 2010. Influence of antecedent hydrologic conditions on patterns of hydrochemical export from a first-order agricultural watershed in Southern Ontario, Canada. Journal of Hydrology 389(1-2):101-110. https://doi. org/10.1016/j.jhydrol.2010.05.034.

Maher, K. 2011. The role of fluid residence time and topographic scales in determining chemical fluxes from landscapes. Earth and Planetary Science Letters 312(12):48-58. https://doi.org/10.1016/j.epsl.2011.09.040.

McCollum, R.E. 1991. Buildup and decline in soil phosphorus: 30-year trends on a Typic Umprabuult. Agronomy Journal 83(12563):77-85. https://doi. org/10.2134/agronj1991.00021962008300030011x.

Menezes-Blackburn, D., H. Zhang, M. Stutter, C.D. Giles, T. Darch, T.S. George, and P.M. Haygarth. 2016. A holistic approach to understanding the desorption of phosphorus in soils. Environmental Science and Technology 50(7):3371-3381.https://doi.org/10.1021/ acs.est. 5 b05395.

Minaudo, C., R. Dupas, C. Gascuel-Odoux, V. Roubeix, P.A. Danis, and F. Moatar. 2019. Seasonal and eventbased concentration-discharge relationships to identify catchment controls on nutrient export regimes. Advances in Water Resources 131(July 2018):103379. https://doi.org/10.1016/j.advwatres.2019.103379.

Murphy, J., and, J.P. Riley. 1962. A modified single solution method for the determination of phosphate in natural waters. Analytical Chemistry ACTA 27:31-36. https:// doi.org/10.1016/S0003-2670(00)88444-5

Murphy, P.N.C., and R.J. Stevens. 2010. Lime and gypsum as source measures to decrease phosphorus loss from soils to water. Water, Air, and Soil Pollution 212(1-4):101111. https://doi.org/10.1007/s11270-010-0325-0.

Nair, V.D., M.W. Clark, and K.R. Reddy. 2015. Evaluation of legacy phosphorus storage and release from wetland 
soils. Journal of Environment Quality 44(6):1956. https://doi.org/10.2134/jeq2015.03.0154.

Nair, V.D., and W.G. Harris. 2014. Soil Phosphorus Storage Capacity for Environmental Risk Assessment. Advances in Agriculture (2014). http://dx.doi. org/10.1155/2014/723064.

R Core Team. 2017. R: A language and environment for statistical computing.Vienna, Austria: R Foundation for Statistical Computing. https://www.r-project.org/.

Radcliffe, D.E., D.K. Reid, K. Blombäck, C.H. Bolster, A.S. Collick, Z.M. Easton, and D.R. Smith. 2015. Applicability of models to predict phosphorus losses in drained fields: A review. Journal of Environment Quality 44(2):614. https://doi.org/10.2134/jeq2014.05.0220.

Rose, L.A., D.L. Karwan, and S.E. Godsey. 2018. Concentration-discharge relationships describe solute and sediment mobilization, reaction, and transport at event and longer timescales. Hydrological Processes 32(18):2829-2844. https://doi.org/10.1002/hyp.13235.

Ruark, M.D., S.M. Brouder, and R.F.Turco. 2009. Dissolved organic carbon losses from tile drained agroecosystems. Journal of Environment Quality 38(3):1205. https:// doi.org/10.2134/jeq2008.0121.

Ruark, M., A. Madison, F. Madison, E. Cooley, D. Frame, T. Stuntebeck, and M. Komiskey. 2012. Phosphorus loss from tile drains: Should we be concerned? Madison, WI: University of Wisconsin. http://fyi.uwex.edu/drainage/ files/2015/09/P-Loss-from-Tile-Drains-ppt.pdf.

Schärer, M., C. Stamm, T. Vollmer, E. Frossard, A. Oberson, H. Flühler, and S. Sinaj. 2007. Reducing phosphorus losses from over-fertilized grassland soils proves difficult in the short term. Soil Use and Management 23(SUPPL. 1):154-164. https://doi. org/10.1111/j.1475-2743.2007.00114.x.

Schilling, K.E., and M. Helmers. 2008. Tile drainage as karst: Conduit flow and diffuse flow in a tile drained watershed. Journal of Hydrology 349:291-30. https:// doi.org/doi:10.1016/j.jhydrol.2007.11.014.

SEAL Analytical. 2004. O-Phosphate-P in drinking, saline and surface waters, and domestic and industrial wastes. AQ2 method EPA-118-A Rev. 5. Mequon, WI: SEAL Analytical, Mequon Technology Center.

Sharpley, A.N., T. Daniel, T. Sims, J. Lemunyon, R. Stevens, and R. Parry. 2003. Agricultural Phosphorus and Eutrophication, Second Edition. Washington, DC: USDA Agricultural Research Service.

Sharpley, A.N., and S. Rekolainen. 1997. Phosphorus in agriculture and its environmental implications. In Phosphorus Loss from Soil to Water, ed. H. Tunney, O.T. Carton, P.C. Brookes, and A.E. Johnston, 1-54. Wallingford, UK: CAB International.

Sharpley, A.N., J.T. Sims, K.R. Reddy, S.C. Chapra, T.C. Daniel, and R. Wedepohl. 1994. Managing agricultural phosphorus for protection of surface waters: Issues and options. Journal of Environment Quality 23(3):437. https://doi.org/10.2134/ jeq1994.00472425002300030006x.
Simard, R.R., S. Beauchemin, and P.M. Haygarth. 2000. Potential for preferential pathways of phosphorus transport. Journal of Environmental Quality 29(1):97-105. https://doi.org/10.2134/ jeq2000.00472425002900010012x.

Sims, J.T., R.R. Simard, and B.C. Joern. 1998. Phosphorus loss in agricultural drainage: Historical perspective and current research. Journal of Environment Quality 27(2):277. https://doi.org/10.2134/ jeq1998.00472425002700020006x.

Stamm, C., R. Sermet, J. Leuenberger, H. Wunderli, H. Wydler, H. Flühler, and M. Gehre. 2002. Multiple tracing of fast solute transport in a drained grassland soil. Geoderma 109(3-4):245-268. https://doi. org/10.1016/S0016-7061(02)00178-7.

Thompson, S.E., N.B. Basu, J. Lascurain, A. Aubeneau, and P.S.C. Rao. 2011. Relative dominance of hydrologic versus biogeochemical factors on solute export across impact gradients. Water Resources Research 47(7):1-20. https://doi.org/10.1029/2010WR009605.

Trybula, E. 2012. Quantifying ecohydrologic impacts of perennial rhizomatous grasses on tile discharge: A plot level comparison of continuous corn, upland switchgrass, mixed prairie, and Miscanthus $\times$ giganteus. PhD dissertation, Purdue University. https://docs.lib. purdue.edu/dissertations/AAI1535171/.

USEPA (US Environmental Protection Agency). 2002. EPA Water Quality Standards Handbook, (August), 2-3. Washington, DC: USEPA.

Uusitalo, R., E. Turtola, T. Kauppila, and T. Lilja. 2001. Particulate phosphorus and sediment in surface runoff and drainflow from clayey soils. Journal of Environmental Quality 30(2):589-595. https://doi. org/10.2134/jeq2001.302589x.

Vadas, P.A., P.J.A. Kleinman, A.N. Sharpley, and B.L. Turner. 2005. Relating soil phosphorus to dissolved phosphorus in runoff: A single extraction coefficient for water quality modeling. Journal of Environmental Quality 34(2):572-580. https://doi.org/10.2134/jeq2005.0572.

Vaughan, M.C.H., W.B. Bowden , J.B. Shanley, A.Vermilyea, R. Sleeper, A.J. Gold, S.M. Pradhanang, S.P. Inamdar, D.F. Levia, A.S. Andres, F. Birgand, and A.W. Schroth. 2017. High-frequency dissolved organic carbon and nitrate measurements reveal differences in storm hysteresis and loading in relation to land cover and seasonality. Water Resources Research 5(3):2-2. https://doi. org/10.1111/j.1752-1688.1969.tb04897.x.

Verbree, D.A., S.W. Duiker, and P.J.A. Kleinman. 2010. Runoff losses of sediment and phosphorus from no-till and cultivated soils receiving dairy manure. Journal of Environmental Quality 39(5):1762-1770. https://doi. org/10.2134/jeq2010.0032.

Vidon, P., and P.E. Cuadra. 2011. Phosphorus dynamics in tile-drain flow during storms in the US Midwest. Agricultural Water Management 98(4):532-540. https://doi.org/10.1016/j.agwat.2010.09.010.
Wagner, L.E., P. Vidon, L.P. Tedesco, and M. Gray. 2008. Stream nitrate and DOC dynamics during three spring storms across land uses in glaciated landscapes of the Midwest. Journal of Hydrology 362(3-4):177-190. https://doi.org/10.1016/j.jhydrol.2008.08.013.

Welikhe, P., S.M. Brouder, J.J. Volenec, M. Gitau, and R.F. Turco. 2020a. Development of phosphorus sorption capacity-based environmental indices for tile-drained systems. Journal of Environmental Quality 49(2):378391. https://doi.org/10.1002/jeq2.20044.

Welikhe, P., S.M. Brouder, J.J.Volenec, M. Gitau, R.F. Turco, and N.S. De Armond. 2020b. Tile discharge, dissolved reactive phosphorus concentrations and loads for the WQFS (Water year 2011 - 2013). West Lafeyette, IN: Purdue University Research Repository. doi:10.4231/ BJHE-3239.

Weng, L., W.H.Van Riemsdijk, and T. Hiemstra. 2012. Factors controlling phosphate interaction with iron oxides. Journal of Environmental Quality 41(3):628-635. https://doi.org/10.2134/jeq2011.0250.

Williams, G.P. 1989. Sediment concentration versus water discharge during single hydrologic events in rivers. Journal of Hydrology 111(1-4):89-106. https://doi. org/10.1016/0022-1694(89)90254-0.

Williams, M.R., A.R. Buda, H.A. Elliott, J. Hamlett, E.W. Boyer, and J.P. Schmidt. 2014. Groundwater flow path dynamics and nitrogen transport potential in the riparian zone of an agricultural headwater catchment. Journal of Hydrology 511:870-879. https://doi.org/10.1016/j. jhydrol.2014.02.033.

Williams, M.R., K.W. King, W.I. Ford, A.R. Buda, and C. Kennedy. 2016. Effect of tillage onmacropore flow and phosphorus transport to tile drains. Water Resources Research 52(4):2868-2882. https://doi. org/10.1002/2015WR017650.Received.

Williams, M.R., S.J. Livingston, C.J. Penn, D.R. Smith, K.W. King, and C.H. Huang. 2018. Controls of event-based nutrient transport within nested headwater agricultural watersheds of the western Lake Erie basin. Journal of Hydrology 559:749-761. https://doi.org/10.1016/j. jhydrol.2018.02.079. 